\title{
Porovnání vlastností hlasu klasických a popových zpěvaček
}

\section{Comparison of Voice Properties of Classical and Pop Female Singers}

Marek Frič / marek.fric@hamu.cz

Iva Podzimková / iva.podzimkova@seznam.cz

Jana Jelínková / yana.jelinkova@gmail.com

Musical Acoustic Research Center, Music and Dance Faculty, Academy Of Performing Arts in Prague, CZ

\begin{abstract}
The aim of this work is to compare perceptual, acoustic and electroglottographic features of voice within six opera female singers and five pop female singers. The analysis was done for vowels $A, I$ and $U$ and was performed on $0.5 \mathrm{~s}$ long samples of scales singing ranging from C4 to $\mathrm{C} 6$ in 4 dynamic levels and samples taken from 4 chosen tones within an octave sung with gradually increased intensity. Evaluation by listening proved a fundamental difference between the perception of darkened colour of the voice with pronounced vibrato typical for opera singers and light, bright and narrow sound without vibrato typical for pop singers. The style of voice modulation, especially the range of pitch modulation (the difference came up to 2 semitones in the highest notes), essentially differentiated individual styles of opera singers. Pop singers had a higher rate of periodical irregularities and also a higher frequency of pitch modulation. Opera singers generally reached higher maximum SPL levels in C5-C6 octave. Pop singers had higher maximum SPL levels only in the middle of C4-C5 octave for vowel A. Electroglottography demonstrated different phonation settings within singing genres. The most significant difference concerned medium and loud dynamic level in the range of one and a half octave, where the voice of pop singers showed higher values of contact quotient of vocal folds. Moreover, the systematic difference was proved in changes of the shape of EGG pulses (from wavegrams) with increasing pitch. Pop singers gradually reduced amplitude in vocal folds decontact area, while opera singers gradually increased relative amplitude of EGG pulses in the same area. Spectral analysis proved fundamental differences especially in lower in lower parts of the vocal range. Opera singers enriched the sound particularly between 2 and $5 \mathrm{kHz}$ by bringing positions of third to fifth formants slightly together. Pop singers had significantly higher energy values in higher parts of vocal range.
\end{abstract}


Acoustic properties have shown that acoustic energy of the pop singers reached higher frequency bands above $5 \mathrm{kHz}$. Global spectral features acoustically differentiated the best opera and pop singing styles, in particular features, which are independent on positions of vowel formants. The darkened timbre of opera voice can be explained by a generally lower larynx position, which also means that the first harmonic is strengthened. Together with thinner vocal folds (less vocal folds contact), the perception of a head voice is stronger. Also, an inertial effect of the vocal tract, which strengthens the oscillations of the entire vocal system, works better. In the C5-C6 octave, opera singers can change register to full head. Those two practices make it possible: preservation of the $\mathrm{M} 2$ mechanism even on the highest notes and tuning the first formant up to the first harmonic. On the other hand, the voice of pop singers is closer to the neutral speaking voice setting of the vocal tract. That means higher larynx position, thicker vocal folds (more vocal folds contact) and often even some noise element.

\section{Key words}

singing genres, perceptual evaluation, popular music, genre differences

\section{Úvod}

Významný rozvoj tzv. komplexních pěveckých technik v posledních dekádách (dánská Complex voice technique ${ }^{1}$, Estill voice model $^{2}$ nebo nizozemská Universal voice technique $^{3}$, př́ípadně australská škola Contemporary Commercial Music Singing ${ }^{4}$ ) ovlivnil i poznatky o tvorbě hlasu. Výsledkem je hlubší pochopení možností ovládání jednotlivých částí hlasového aparátu a s tím spojena výsledná kvalita a barva hlasu. Oproti charakterizaci klasické pěvecké techniky, která se snaží zapojením různých rezonancí vyrovnat přechody mezi rejstříky a vytvořit ucelenou barvu a obrovský akustický výkon, neklasické styly se soustřed'ují na nové zvukové vlastnosti jako např. belting, twang, overdrive, metallic quality a různé typy drsnosti. Odlišná práce s hlasem u různých stylů pak vede k výrazně odlišným vlastnostem hlasu, které se i jednodušeji zkoumají v komparativních experimentech, kde právě klasický styl zůstává zlatým standardem. Rozdíly v tvorbě hlasu mezi jednotlivými styly byly popsány na všech úrovních tvorby hlasu.

I když na základě experimentálních prací nelze najít jednotnou dechovou techniku ani u klasických stylůn , tlakové hledisko (použitý subglotický tlak) bylo zdokumentováno jako

1 SADOLIN, K. Complete vocal technique. Copenhagen: Shout Publishing, 2000.

2 STEINHAUER, K. - MCDONALD KLIMEK, M. - ESTILL, J. The Estill Voice Model: Theory E Translation Book. Pittsburgh, Pennsylvania: Estill Voice International, 2017.

3 Universal voice: UV system [online]. [cit. 2020-02-19]. Dostupné z: https://universalvoice.nl/uv-system.

4 NASIMITH, M. L. Toward a 21 century contemporary commercial music (CCM) singing pedagogy. In: Pan-European Voice Congerence: Book of abstracts. Copenhagen: University of Copenhagen, 2019, s. 67-68.

5 SUNDBERG, J. Articulatory interpretation of the „singing formant“, J Acoust Soc Am, 1974, roč. 55, č. 4, s. 838-844; THOMASSON, M. - SUNDBERG, J. Consistency of inhalatory breathing patterns in professional 
základní parametr odlišující styly ${ }^{6}$. Percepčně se projevuje jako „pressedness“. Uvedené zjištění je podpořeno i faktem, že klasičtí operní pěvci tvoří hlas s vyšší hladinou první harmonické složky L(H1) než muzikáloví7. Hlas klasických zpěváků pak působí plněji bez výraznějších známek „tlaku“8. Vyšší hodnoty L(H1) lze považovat za následek určitého typu rezonance typického pro klasický zpěv (pravděpodobně hlavová rezonance) ${ }^{9}$.

Na úrovni kmitání hlasivek, tedy z hlediska vibračních mechanismů (rejstříků), byly také zjišsěny odlišnosti. Různé použití hrtanu bylo potvrzeno např. vyššími hodnotami kontaktu hlasivek (tedy vyšší mírou addukce) u neklasických zpěváků, a to mužů i žen ${ }^{10}$. Subglotický tlak v zásadě narůstal se stoupající výškou hlasu a byl vyšší u muzikálových pěvců. M1 mechanismus kmitání je základním typem kmitání hlasivek, typický pro běžnou řeč mužů i žen, ale taky charakteristický pro klasický zpěv mužů ${ }^{11}$ nebo pro neklasický zpěv mužů i žen (rozdílné je v tomto případě zejména rezonanční hledisko).

U neklasických stylů zpěvu žen a také u klasického zpěvu mužů je k hrudnímu rejstř́iku přiřazována speciální technika „belting“, typická pro vysoké polohy a vysoké intenzity hrudního rejstříku ${ }^{12}$, který leží nad passaggio primo v M1 mechanismu ${ }^{13}$. Neklasické zpěvačky využívají M1 mechanismus také pro chest a chestmix rejstř́ky, kde chestmix má víc energie v oblasti základní frekvence než chest, ale menší aktivitu TA a menší míru addukce. Aktivita CT v této studii byla dána zejména výškou ${ }^{14}$. Výraznější použití M1 mechanismu na druhé straně vede $\mathrm{k}$ menšímu rozsahu hlasu u neklasických zpěvákư ${ }^{15}$, zejména pokud se jedná o konkrétní barvu.

Rezonanční vlastnosti jsou ovlivněny zejména odlišným zpo̊sobem artikulace vokálů, projevující se na polohách prvních dvou vokalických formantů ${ }^{16}$, nebo strategií hrtanové

operatic singers, J Voice, 2001, roč. 15, č. 3, s. 373-83; THOMASSON, M. Belly-in or belly-out? TMH-QPSR, 2003, roč. 45, č. 1, s. 61-73.

6 THALEN, M. - SUNDBERG, J. Describing different styles of singing: a comparison of a female singer's voice source in „Classical“, „Pop“, „Jazz“ and „Blues“, Logoped Phoniatr Vocol, 2001, roč. 26, č. 2, s. 82-93.

7 BJÖRKNER, E. Musical theater and opera singing-why so different? A study of subglottal pressure, voice source, and formant frequency characteristics. J Voice, 2008, roč. 22, č. 5, s. 533-540.

8 BERGAN, C. C. - TITZE, I. R. - STORY, B. The perception of two vocal qualities in a synthesized vocal utterance: ring and pressed voice. J Voice, 2004, roč. 18, č. 3, s. 305-317.

9 FRIČ, Marek. Strategie poslechového hodnocení rezonance hlasu. In Nové trendy akustického spektra - vedecký recenzovaný zbornik, Zvolen: Material - Acoustics - Place, 2014, s. 73-80.

10 BARLOW, C. - LOVETRI, J. Closed quotient and spectral measures of female adolescent singers in different singing styles. J Voice, 2010, roč. 24, č. 3, s. 314-318; BJÖRKNER, op. cit., s. 533-540.

11 MILLER, D.G. Registers in Singing. Empirical and Systematic Studies in the Theory of the Singing Voice. Groningen, 2000. Disertační práce. University of Groningen.

12 MILLER, op. cit.

13 KOCHIS-JENNINGS, K. A. - FINNEGAN, E. M. - HOFFMAN, H. T. - JAISWAL, S. Laryngeal muscle activity and vocal fold adduction during chest, chestmix, headmix, and head registers in females, $J$ Voice, 2012, roč. 26, č. 2, s. 182-93; BESTEBREURTJE, M. E. - SCHUTTE, H. K. Resonance strategies for the belting style: results of a single female subject study.J Voice, 2000, roč. 14, č. 2, s. 194-204.

14 KOCHIS-JENNINGS, op. cit.

15 ECKLEY, C. A. - SATALOFF, R. T. - HAWKSHAW, M. - SPIEGEL, J. R. - MANDEL, S. Voice range in superior laryngeal nerve paresis and paralysis, J Voice, 1998, roč. 12, č. 3, s. 340-348.

16 STONE, R. E., Jr. - CLEVELAND, T. F. - SUNDBERG, P. J. - PROKOP, J. Aerodynamic and acoustical 
rezonance, projevující se v odlišné poloze vy̌̌ších formantů, a způsobu jejich klastrování. To je typické zejména pro klasický pěvecký formant ${ }^{17}$. Uvedený formant je významný zejména u mužského klasického zpěvu a souvisí se speciální artikulací hypopharyngu a jeho přechodu do hrtanu ${ }^{18}$.

Významný vliv ladění formantů byl dokumentován mezi neklasickými pěveckými styly. Pojem rezonance má výrazně odlišné významy v různých podoborech vokologie. Ve zpěvu se tím myslí zejména spolukmitání jednotlivých částí a dutin těla, kdežto akustika se opírá čistě o prezentaci lokálního maxima ve spektru zvuku v podobě formantu ${ }^{19}$. Jedním ze základních projevů rezonančního efektu, který je pak doprovázen nelineární interakcí zdroje zvuku (kmitání hlasivek) a rezonancí vokálního traktu, je ladění formantů (formant tuning) ${ }^{20}$. Tento jev je nejvíce spojován s technikou tvorby tónů alikvotního zpěvu (overtone singing). Nicméně byl také doložen u klasických i neklasických stylů.

U techniky belt byla pozorována strategie ladění první rezonance s druhou harmonickou složkou (R1:H2) a obecně vyšší poloha R1 než u stylu legit. Rozdíly naopak nebyly pozorovány u druhého rezonančního maxima $(\mathrm{R} 2)^{21}$. Styly chesty a twangy belt se odlišovaly strategií ladění R2. U twangy belt bylo pozorováno systematické ladění R2, navíc obecně ve vyšší frekvenční poloze než v případě chesty belt. Rozdíly mezi uvedenými styly ale nenastaly v glotických parametrech (CQ). Ladění F1:H2 u techniky chorvatského zpěvu „ojkanje“ bylo dokumentováno v celém rozsahu výšky ${ }^{22}$. U dospívajících zpěvaček se předpokládala větší rezonance (ladění $\mathrm{F} 2$ ) v případě stylu musical theater (MT), který se na rozdíl od klasického stylu projevuje výraznějším posílením 3.-5. harmonické složky ${ }^{23}$. Toto zesílení je pravděpodobně zodpovědné za „bright“ a „edgy“ barvu u MT stylu oproti kulaté (rounded) barvě u klasického zpěvu.

Různé způsoby ladění formantů v kombinaci s použitým vibračním mechanismem M2 nebo M3 dokáže od sebe odlišit strategie tvorby vysokých tónů klasických sopránů․ V M2 mechanismu jsou tvořeny lower middle a upper middle rejstř́ky, jejich percepční odlišení je dáno nástupem ladění R1:F0 při jejich přechodu. V M3 jsou tvořeny upper a flageolet rejstř́iky, jejich odlišení je v tomto případě dáno nástupem ladění R2:F0. Pro

measures of speech, operatic, and Broadway vocal styles in a professional female singer. J Voice, 2003, roč. 17, č. 3, s. 283-297.

17 BJÖRKNER, op. cit., s. 533-540.

18 SUNDBERG, op. cit.

19 Bližší vysvětlení viz KUČERA, M. - FRIČ, M. - FRITZLOVÁ, K. - HALÍŘ, M. Vokologie I: funkční diagnostika a léćba hlasových poruch. Praha: Akademie múzických umění v Praze, 2019, s. 74-81.

20 TITZE, I. R. A theoretical study of F0-F1 interaction with application to resonant speaking and singing voice, J Voice, 2004, roč. 18, č. 3, s. 292-298.

21 BOURNE T. - GARNIER M. Physiological and acoustic characteristics of the female Music Theater voice, J Acoust Soc Am, 2012, roč. 131, č. 2, s. 1586-1594.

22 BOERSMA P. - KOVACIC G. Spectral characteristics of three styles of Croatian folk singing, J Acoust Soc $A m, 2006$, roč. 119 , č. 3, s. 1805-1816.

23 BARLOW - LOVETRI, op. cit.

24 GARNIER, M. - HENRICH, N. - CREVIER-BUCHMAN, L. - VINCENT, C. - SMITH, J. - WOLFE, J. Glottal behavior in the high soprano range and the transition to the whistle register, J Acoust Soc Am, 2012, roč. 131, č. 1, s. 951-962. 
uvedené přechody byly zjištěny ještě další dvě strategie. První typ využívají většinou koloraturní soprány. Použijí percepční přechod na spodní hranici využívající R1:F0 ladění, které je možné již od c“ (typický přechod lower middle a upper middle rejstříků), a zároveň ho spojí s přechodem mechanismů M2 do M3. Druhá strategie, typická spíše pro lyrické a dramatické soprány, využívá rozšíření M2 mechanismu až do okolí c' ', , kde je zároveň horní hranice R1:F0 ladění. To ukazuje, že nad passaggio primo přechodem můžou soprány vykazovat ještě další dva nebo tři přechody, ale ty mohou mít bud' charakter přechodu M2-M3 nebo se může jednat o změnu rezonanční strategie ladění formantů.

Práce s vokálním traktem tvoří samostatnou kapitolu, která výrazně ovlivňuje výslednou barvu/kvalitu zvuku. Významný přehled možností práce s vokálním traktem poskytuje Estill Voice Model ${ }^{25}$, který rozeznává 13 figur a následně 6 kvalit hlasu, které popisuje jako kombinaci nastavení a použití uvedených figur. Například operní kvalitu popisuje jako produkci hlasu s měkkým hlasovým začátkem, s široce otevřenými nepravými hlasivkami, využívající jak tlusté, tak tenčí hlasivky s výrazným nakloněním štítné chrupavky, ale bez naklonění prstencové chrupavky. Operní zpěváci často využívají zúžení ary-epiglotického svěrače (hrtanového hrdla) a je pro ně charakteristická hlubší poloha hrtanu se zvýšenou polohou hřbetu jazyka při vysoké poloze měkkého patra (zavřený velo-faryngeální uzávěr). Využívají střední polohu spodní čelisti a rtů. Operní pěvci také využívají výrazné ukotvení hrudníku, hlavy a krku. Naproti tomu beltingová kvalita používá navíc i tvrdý hlasový začátek, v zásadě využívá tlustý tvar hlasivek, nerotuje štítnou, ale naopak prstencovou chrupavku a používá vysokou polohu hrtanu. Ostatní figury mají opera i belt podobné.

Změna tvaru vokálního traktu akusticky mění polohy všech formantů, zejména pozice prvních dvou. Délka průdušnice významně ovlivňuje nelineární interakci zdroje (kmitání hlasivek) a filtru (vokálního traktu). Předběžné studie srovnávající tvar vokálního traktu dobře odlišily strategie tvorby vysokých tónů mužư ${ }^{26} \mathrm{i}$ žen ${ }^{27}$ mezi operním zpěvem a beltingem. Pro belting je charakteristické posílení druhé harmonické složky. To nutí zpěváky posouvat polohu prvního formantu co nejvýše, aby i druhá harmonická složka spadala do frekvenční oblasti pod pozicí prvního formantu. Z tohoto důvodu belteři využívají zejména tvar podobný otevřenému megafonu (podobný tvaru trumpety, tedy postupně se rozšiřující vokální trakt s narůstající vzdáleností od hlasivek). Naproti tomu charakter operních vokálních traktů má tvar invertovaného megafonu (v zásadě lze typický operní tvar vokálního traktu charakterizovat relativně úzkým hrdlem hrtanu (epilaryngu), následně širokou hrtanovou dutinou ${ }^{28}$, maximálně rozšířený vokální trakt je v ústní dutině a následně se k ústnímu otvoru znovu zužuje). Tento tvar vokálního traktu, společně s prohloubenou polohou hrtanu, posouvá zejména první formant směrem k hlubším frekvencím. Tím je dosaženo posílení hlavně první harmonické složky s relativně velkým utlumením druhé harmonické složky. Otevření vokálního traktu je nutno rozšiřovat

25 STEINHAUER, et al., op. cit.

26 TITZE, I. R. - WORLEY, A. S. Modeling source-filter interaction in belting and high-pitched operatic male singing. The Journal of the Acoustical Society of America, 2009, roč. 126, č. 3, s. 1530-1540.

27 TITZE, I. R. - WORLEY, A. S. - STORY, B. H. Source-vocal tract interaction in female operatic singing and theater belting. Journal of Singing, 2011, roč. 67, č. 5, s. 561-572. 
směrem k vyšším tónům a následně vokály ekvalizovat tak, aby první harmonická složka neskočila nad polohu prvního formantu. V takovém př́ípadě by totiž hrozilo výrazné utlumení průtoku vzduchu přes glottis a destabilizace tvorby tónu s charakteristickými rejstř́kovými zlomy.

\section{Cíle}

Cílem publikace je porovnání percepčních, akustických a vibračních vlastností hlasu mezi skupinami klasických a popových zpěvaček a popis zásadních rozdílů mezi pěveckými styly.

\section{Materiál a metody}

\section{Subjekty a záznam jejich hlasu}

K měření byla vybrána skupina 6 klasických zpěvaček a 5 popových, jejichž údaje jsou uvedeny v Tab. 1.

Tab. 1 Popis typu hlasu, věku a hudebního vzdělání měřených zpěvaček.

\begin{tabular}{|l|l|r|l|}
\hline ID & Žánr & Věk & Hudební vzdělání \\
\hline K1 & Lyrický soprán & 25 & $\begin{array}{l}\text { soukromé lekce (9 let, úroveň konzervatoře), workshopy } \\
\text { pořádané Pražskou konzervatoří (klasický zpěv) }\end{array}$ \\
\hline K2 & Lyrický soprán & 31 & Konzervatoř v Plzni (6 let), HAMU - operní zpěv (3 roky) \\
\hline K3 & Lyricko koloraturní soprán & 31 & Konzervatoř v Kroměříi (6 let), HAMU - operní zpěv (5 let) \\
\hline K4 & Mladodramatický soprán & 31 & Konzervatoř v Ostravě (6 let), HAMU - operní zpěv (4 roky) \\
\hline K5 & Lyrický soprán & 25 & Pražská konzervatoř (6 let), HAMU - operní zpěv (4 roky) \\
\hline K6 & Dramatický soprán & 28 & Pražská konzervatoř (6 let), HAMU - operní zpěv (3 roky) \\
\hline P1 & Pop soprán & 25 & Pražská konzervatoř - pop zpěv (6 let), CVT workshopy \\
\hline P2 & Pop soprán & 20 & Pražská konzervatoř - pop zpěv (5 let) \\
\hline P3 & Pop a muzikálový soprán & 21 & Pražská konzervatoř - pop zpěv (6 let) \\
\hline P4 & Pop a muzikálový soprán & 22 & Pražská konzervatoř - pop zpěv (6 let) \\
\hline P5 & Pop soprán & 22 & Pražská konzervatoř - pop zpěv (6 let) \\
\hline
\end{tabular}

Studie je pokračováním předchozí práce ${ }^{29}$, ve které byly měřeny vyzařovací vlastnosti hlasu zpěvaček. Popis měřicího řetězce je uveden v apendixu - část Záznam hlasu a elektroglotografie.

29 FRIČ, Marek a Iva PODZIMKOVÁ. Comparison of sound radiation between classical and pop singers. Biomedical Signal Processing and Control [online]. 2021, roč. 66 [cit. 2021-09-01]. Dostupné z: doi:10.1016/j. bspc.2021.102426 
V uvedeném nastavení byly nahrány stupnice od c' do c' '' zpívané neutrálním módem na samohlásky /a/, /i/, / u/ ve čtyřech různých dynamikách $(p, m f, f, f f)$. Dále byly na tónech c, dis, fis, a v obou měřených oktávách zaznamenány prodloužené fonace všech vokálů při postupném zesilování hlasitosti. Neklasické zpěvačky zpívaly v módu neutrálním, klasické zpěvačky byly požádány, aby co nejvíce tlumily své vibrato.

V programu RealVoiceLab (vyvinut v prostředí MATLAB ${ }^{30}$ ) byl zvukový signál z mikrofonu rozstříhán na výseky zakmitaného stavu signálu, čili kvazistacionární části vokálu. Pro další analýzu byly akceptovány jenom výstřihy s délkou 500 ms. Tímto vznikly střihové databáze s informacemi o průměrné výšce (přepočítány do škály MIDI) a průměrné hladině akustického tlaku (SPL).

Popis akustické parametrizace a statistického zpracování výsledků je uveden v apendixu v části Parametrizace akustického signálu.

\section{Poslechové hodnocení}

Stimulové ukázky byly vybrány jenom ze tří výšek hlasu, a to c', a', fis ' '. Pro každou výšku a vokál byla zvolena SPL, ve které se překrývalo největší množství výstřihů klasických i popových zpěvaček. Předvýběr byl vytvořen ze všech vzorků, spadajících do zvolené oblasti hlasového pole s nejhustším zastoupením vzorků všech zpěvaček. Finální výběr proběhl na základě poslechu autorem. Z předvýběru vzorků jedné zpěvačky byl vybrán reprezentant s nejmenší nestabilitou výšky.

$\mathrm{V}$ poslechovém testu (grafické rozhraní viz Obr. A1 v apendixu) byla v náhodném pořadí hodnocena každá stimulová nahrávka zvlášt́. Na škále Charakter hlasu bylo hodnoceno, jestli je zvuk více nebo méně typický pro popový nebo operní styl. Do textových polí byly pak popsány vlastnosti, které obsahuje nahrávka a jsou spíše typické pro operní, respektive popový styl. Také byla nabídnuta možnost popsat jiné vlastnosti, které nejsou charakteristické ani pro jeden z uvedených stylů.

Zpracování výsledků poslechového hodnocení je podrobněji popsáno v apendixu v části Poslechový test.

\section{Objektivní parametrizace}

Zpracování akustického a elektroglotografického signálu je podrobně rozebráno v apendixu v části Doplněk metodické části.

30 MATLAB and Statistics Toolbox Release 2011b [počítačový program], Natick, Massachusetts, United States: The MathWorks, Inc. 2011. 


\section{Výsledky}

\section{Porovnání dynamik}

Obr. 1 zobrazuje naměřené průměrné hodnoty hladin akustického tlaku (SPL) ve vzdálenosti $1,26 \mathrm{~m}$ v měřeném dvouoktávovém rozsahu v dynamikách $f f, m f, m p, p$ a při postupném zesilování hlasu (crescendo). Statisticky významné rozdíly jsou označeny v konkrétních polohách hlasu zeleným kosočtvercem a velmi významné rozdíly černou hvězdičkou. Ve všech měřených úkolech dosahovaly klasické zpěvačky v průměru vyšších hodnot SPL, avšak statisticky potvrzené rozdíly ležely v zásadě jen v druhé oktávě. Jedinou výjimkou je ff dynamika u vokálu $\mathrm{A}$, kde v celé jednočárkované oktávě měly vyšší průměrné hodnoty SPL popové zpěvačky, statisticky významně vy̌šsí hodnoty měly uprostřed první oktávy.
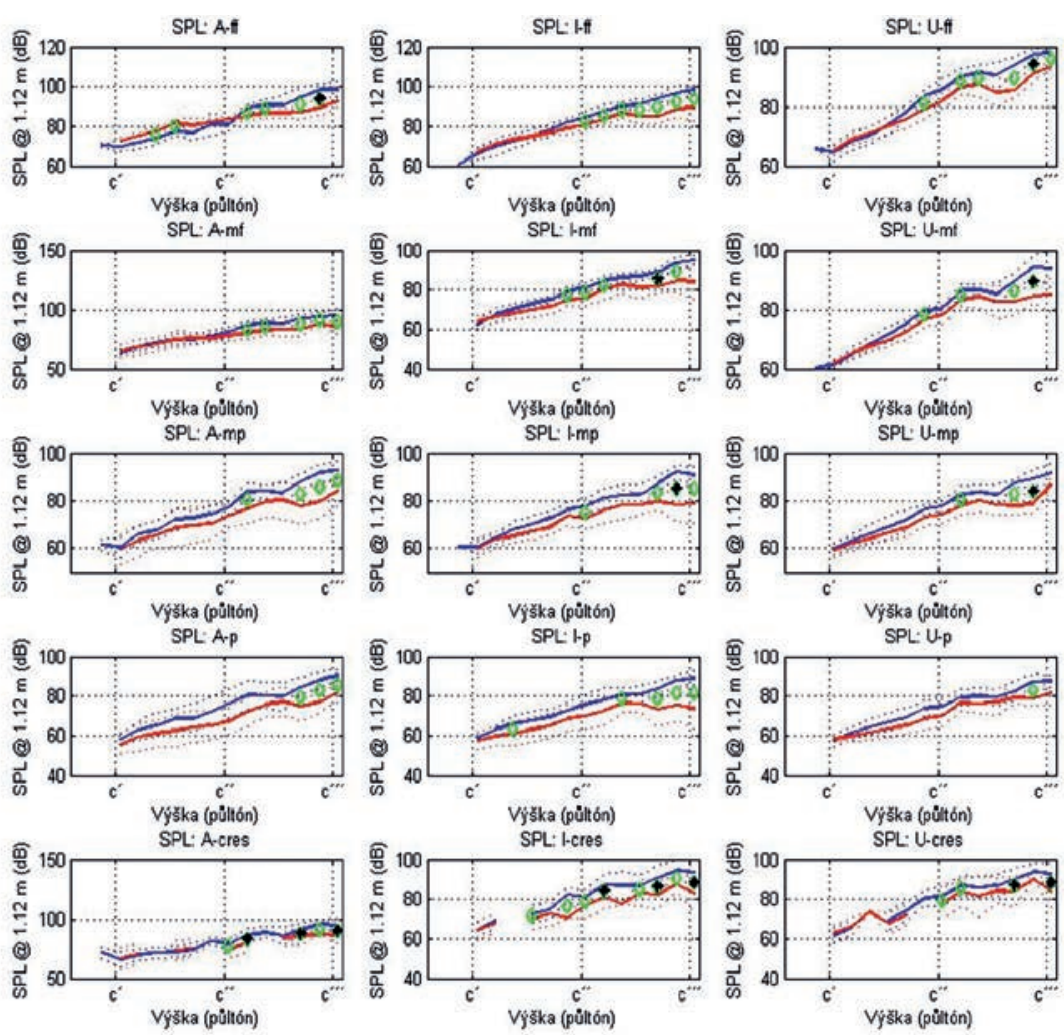

Obr. 1 Porovnání naměřených průměrných hodnot SPL (tlusté plné čáry) a jejich směrodatných odchylek (tenké, čárkované čáry) ve vzdálenosti 1,26 m mezi klasickými (modrá) a popovými (červená) pro jednotlivé dynamiky při zpěvu stupnic a crescenda, zvlášt' pro každý vokál. Výškové polohy, kde byly průměrné hodnoty SPL dle nepárového t-testu statisticky významně odlišné, jsou vyznačeny zelenými kosočtverci $(p<0,05)$ a černými hvězdičkami $(p<0,001)$. 


\section{Výsledky poslechového hodnocení vokálů}

Výsledky hodnocení charakteru zvuku stimulových ukázek (popový vs operní) jsou pro všechny vokály zakresleny na Obr. 2. Míra hodnocení pop-klas nabývala hodnot od -50, což značí jednoznačně popový typ zvuku až po +50 , což odpovídá jednoznačně opernímu zvuku. Hodnoty mezi -25 až 25 ukazují relativně velkou nejistotu v hodnocení charakteru zvuku. Vzájemná shoda tří hodnotitelů byla výborná u vokálů A a I, a velmi dobrá pro vokál U, jak je uvedeno v tabulce A1 v apendixu.

Slovní popis shrnuje typické vlastnosti pro jednotlivé styly. Souhrnně je uveden v tabulkách A1 a A2 v apendixu. Nejčastěji byla při popisu popových zvuků všemi hodnotiteli použita slovní spojení: bez vibrata, rovné, světlé a drsnost. Méně významná (nepoužili je všichni hodnotitelé), ale velmi častá byla spojení: slabši pěvecký formant, řečového charakteru, neopřené, jasné, ostré, volné, dyšné. Při popisu operních zvuků byla nejčastěji použita spojení: vibrato a tmavší zvuk. Méně specifické byly popisy jako: hlavová barva, pěvecký formant, plnost a flétnovost.

Dle mediánového škálového hodnocení charakteru zvuku a rozptylu hodnocení je dobře vidět, že s narůstající výškou se obecně posouvalo i hodnocení charakteru vybraných ukázek směrem k více opernímu. Malou výjimku tvoří výška a’ u vokálu $\mathrm{A}$, kde hodnocení popových ukázek dosahovalo obecně nejvyšší míru operního charakteru zvuku. Většinu stimulových nahrávek lze celkově hodnotit jako reprezentanty originálního stylu zpěvačky. Zvuky, které neodpovídají originálnímu stylu zpěvaček, resp. patří do neutrální zóny, dále rozvíjejí popis vlastností, které výrazně ovlivňují charakterizaci stylů.

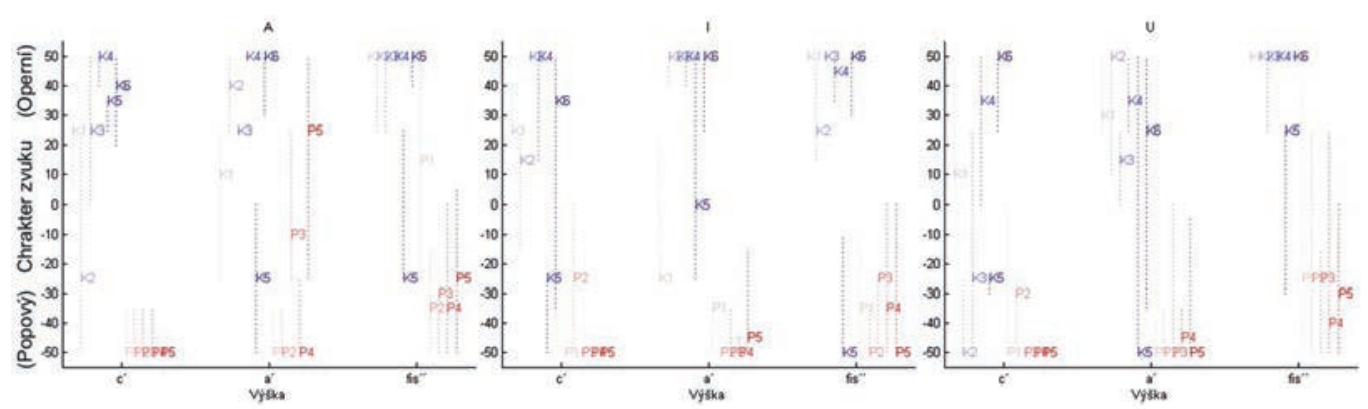

Obr. 2 Výsledné hodnoty mediánů (označení dle subjektu) a celkových rozsahů (tečkované čáry) hodnocení na škále Charakter zvuku (popový vs operní).

U vokálu A byly ukázky operní zpěvačky K2 ve výšce c' a zpěvačky K5 ve výškách a ' a fis' ' hodnoceny jako „spíše popového charakteru“. Ukázky K1 a K3 ve výškách c' a a ' byly hodnoceny jako „méně operní“. Ukázky P3 a P5 ve výšce a' a P1 na fis ” byly hodnoceny jako „neutrální“, resp. „mírně operní“. Jejich hodnocení je uvedeno v tabulce A4 v apendixu. Ze slovního popisu vyplývá, že s nárůstem šumu a drsnosti, se zeslabením energie pěveckého formantu a celkové dynamiky, se zmenšením charakteru hlavové 
barvy a s absencí vibrata se stávají zvuky klasických zpěvaček více popové. Naopak s nárůstem vibrata, hlavové barvy, se zesílením pěveckého formantu, zatmavením a snížením polohy hrtanu se zvuk popových zpěvaček stává více operním.

U vokálu I (hodnocení je zobrazeno v tabulce A5 v apendixu) byly neodpovídajícím stylem hodnoceny ukázky zejména u operních zpěvaček, a to všechny ukázky K5, K1 ve výšce $\mathrm{a}^{\prime}$. Dále jako méně operní byly hodnoceny ukázky K1 a K2 ve výšce c', K2 na fis ' '. Popové zpěvačky v zásadě odpovídaly popovým zvukům, nejméně však P2 na c' a P3 na fis' '. Popový charakter zvuku vytvářely operní zpěvačky při menší míře vibrata a s menším zastoupením vyšších harmonických složek a opory, ale s nárůstem šumu v hlase, drsnosti, světlosti, ostrosti a řečového charakteru hlasu. Popové zpěvačky měly nejméně popový charakter, pokud zvýraznily vibrato, flétnový charakter zvuku a zvýraznily hlavovou barvu a měly temnější hlas.

Vokál U se u zvuků operních zpěvaček K2, K3 a K5 ve výšce c' a u K5 při a ' měl výrazně popový charakter. Nejméně operně působily zvuky operních zpěvaček K1 pří c', K3 a K6 v a', K5 ve fis' '. Jako méně popové působily zvuky popových zpěvaček P1, P2 a P3 ve fis' '. Jejich slovní popis je uveden v tabulce A6 v apendixu. Popový charakter narůstal ve směru snižování vibrata a se slabším formantem, ale s nárůstem rovného hlasu, povolení, světlosti a s řečovým charakterem zvuku. Popové zpěvačky zněly jen méně popově, pokud měly flétnovou a hlavovou barvu a slyšitelný formant.

\section{Vlastnosti modulace hlasu (vibrato)}

Modulační vlastnosti držených tónů byly analyzovány metodou 4-way ANOVA, kde byl zjištován nezávisle vliv faktorů žánr, vokál, výška a intenzita hlasu (výsledky viz Tab A7 v apendixu). Sledované žánry se výrazně odlišovaly zejména v parametrech výškové modulace a v rozsahu intenzitní modulace, kde jako jediný měl vliv i typ vokálu. Výška hlasu ovlivňovala všechny parametry kromě periodické nepravidelnosti obou obou typů modulací a SPL mělo vliv na frekvenci a rozsah výškové modulace a rozsah a periodickou nepravidelnost intenzitní modulace.

Na Obr. A2 v apendixu lze pozorovat rozložení měřených parametrů modulace hlasu (vibrata) v hlasovém poli a rozdíly mezi žánry. Frekvence modulace výšky hlasu se v zásadě pohybovala mezi 5-6 Hz u klasických zpěvaček, kdežto popové zpěvačky měnily frekvenci modulace od 4 až do $8 \mathrm{~Hz}$. Statisticky významně vyšší hodnoty však měly jenom ve své $f f$ dynamice v polohách cca f' - f' '. Amplituda výškové modulace byla nejvýznamnější parametr odlišující žánry. Popové zpěvačky modulovaly výšku v rozmezí do 0,75 půltónu, kdežto v celém překrývajícím se hlasovém poli měly klasické zpěvačky vyšší rozsah modulace. Ten se pohyboval v rozmezí $0.75-2$ půltóny, přičemž nejvy̌šsí hodnoty dosahovaly v $m f$ a $f f$ dynamice v dvoučárkované oktávě. Nepravidelnost periody výškové modulace byla vyšší u popových zpěvaček, zejména ve vyšší oktávě, kdežto vyšší míru nepravidelnosti rozsahu modulace měly klasické zpěvačky v hlubších $2 / 3$ měřeného rozsahu. 
Modulace intenzity neprokázala nějaký jednoznačný standard odlišností stylů, ale dle parametru rozsah modulace intenzity výrazněji dominovaly klasické zpěvačky, zejména v $m p$ a $m f$ dynamice v celém výškovém rozsahu. Nepravidelnost periody i rozsahu intenzitní modulace prokazovaly jenom ojedinělé rozdíly.

\section{EGG parametry (kmitání hlasivek)}

Analýza rozptylu dle 4 faktorů (žánr, vokál, výška a SPL) viz tab. A8 ukazuje, že hodnoty kontaktního koeficientu $(\mathrm{CQ})$ jsou nejvýrazněji ovlivněny žánrem, pak intenzitou, vy̌škou a nejméně typem vokálu. Faktorová analýza rozptylu pro ff dynamiku a zvlášt pro jednotlivé vokály ukázala jenom odlišnosti na základě žánru pro vokály A a I. Pro vokál U nebyl zjištěn významný rozdíl a výška hlasu se v těchto případech také nepodílela na rozdílech změřeného CQ.

Porovnání průměrných hodnot $\mathrm{CQ}$ v jednotlivých částech hlasového pole (viz Obr. A3 v apendixu) ukázalo významně vyšší hodnoty $\mathrm{CQ}$ pro popové zpěvačky ve střední až velmi hlasité dynamice $\mathrm{v}$ hlubší části měřeného rozsahu. Klasické zpěvačky měly jenom ojediněle vyšší CQ v přechodové oblasti a nejtišší dynamice. Porovnání jednotlivých vokálů a 4 měřených dynamik ukázalo, že rozdíly byly jenom $\mathrm{v}$ ff dynamice, u vokálu A v dolních dvou třetinách měřeného rozsahu, u vokálu I jen v nejhlubší polovině oktávy a u vokálu U jen na tónu g'. V tišších dynamikách měly vyšší hodnoty CQ klasické zpěvačky v nejvyšším tónu c'”.

Porovnání průměrných normalizovaných pulzů (dle metody vytváření wavegramů dle Herbst et al., 2010 ${ }^{31}$ ) mezi typy zpěvaček a čtyřmi měřenými dynamikami je samostatně pro 12 výšek zobrazeno na Obr. A4 v apendixu. Dle znázorněných pulzů lze dobře pozorovat, že popové zpěvačky mají obecně širší EGG pulsy, tedy lze u nich očekávat větší dobu kontaktu hlasivek. Efekt tří faktorů na normalizované pulzy obecně nejméně ukazuje vliv vokálu, který se nejčastěji nachází ve fázi otevření hlasivek. Výrazněji se projevuje efekt dynamiky, který ovlivňuje oblast těsně před maximálním kontaktem (uzávěrem) hlasivek. Nejvýznamnější je efekt žánru, který ovlivňuje téměř celou periodu EGG pulsů až do e "', kdežto u f' ' je podstatně menší vliv kolem fáze maximálního otevření hlasivek a u c" ' je opět vysoký efekt v celé fází otevírání hlasivek.

Efekt změny výšky na normalizované EGG pulsy ve čtyřech dynamikách je znázorněný na Obr. 3. Obrázek ukazuje statisticky významné lineární trendy, hodnotu směrnice přímky mezi hodnotami pulsu (y-ová osa) v jednotlivých částech podél časové osy (x-ová osa) a konkrétní výškou v desetinách jednotek na oktávu. Tam, kde se nachází tečky/ hvězdičky nad šedou čarou (s hodnotou 0), je kladný lineární trend, tedy s narůstající výškou se zvyšuje lokální amplituda v dané části EGG pulsu. Pokud je hodnota záporná, korelace je záporná a s nárůstem výšky se amplituda normalizovaného EGG pulsu snižuje. Zjištěné výsledky ukazují relativně velkou část EGG pulsů, které jsou v lineární

31 HERBST, C. T. - FITCH, W. T. - ŠVEC, J. G. Electroglottographic wavegrams: a technique for visualizing vocal fold dynamics noninvasively. J Acoust Soc Am, 2010, roč. 128, č. 5, s. 3070-3078. 
závislosti se změnou výšky. Výsledky ukazují podobné trendy změn EGG pulzu pro klasické i popové zpěvačky v oblastech strmé náběhové hrany EGG pulzu (tedy fáze uzavírání hlasivek) až po maximum kontaktu hlasivek, kde se nárůstem výšky amplituda systematicky snižuje. Protichůdné změny tvaru pulsů mezi typy zpěvaček se projevily v oblasti otevírání hlasivek a oblasti maximálního otevření. U klasických zpěvaček lze pozorovat trend zvyšování amplitudy, kdežto u popových zpěvaček snižování amplitudy - statisticky významné jen pro ff a mf dynamiku. Uvedené rozdíly indikují systematicky odlišnou změnu tvaru pulsu při nárůstu výšky hlasu v oblasti dekontaktní fáze kmitání hlasivek mezi jednotlivými pěveckými styly.
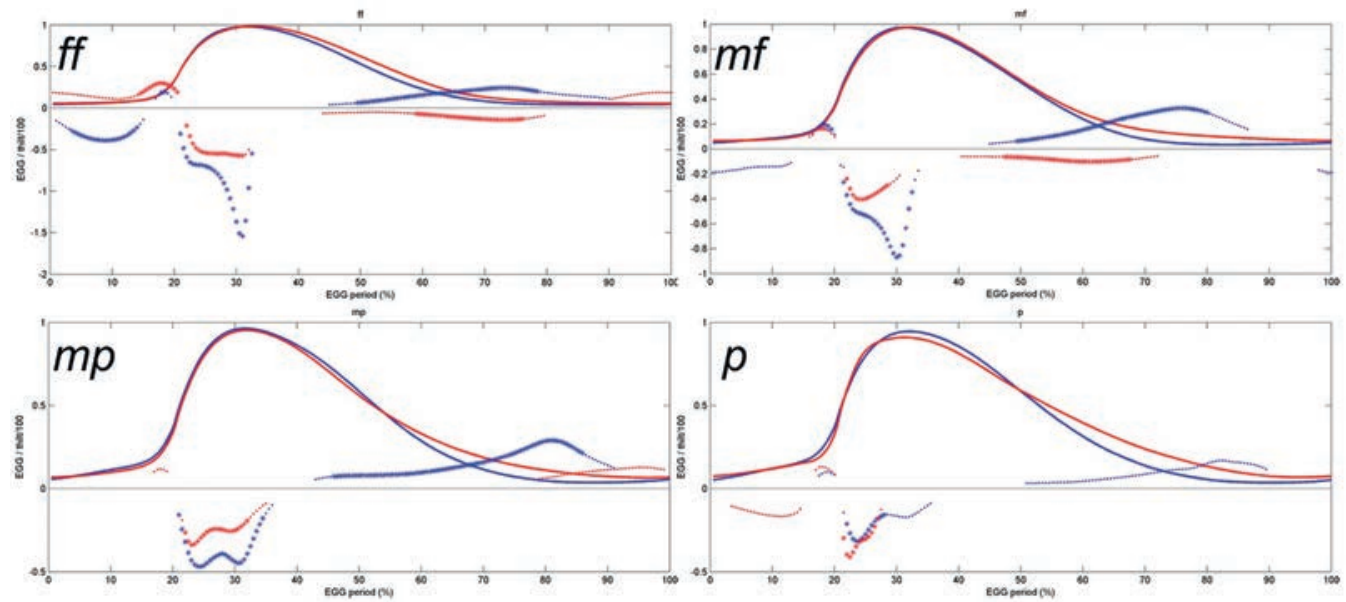

Obr. 3 Průměrné normalizované pulsy (plné tlusté čáry) pro klasické (modrá) a popové (červená) zpěvačky ve čtyřech dynamikách a statisticky významné (tečky $p<0.05$, hvězdičky $\mathrm{p}<0.001$ ) hodnoty sklonu lineárního trendu mezi výškou a hodnotou normalizovaného EGG pulsu.

Vliv změny dynamiky na normovaný pulz je zobrazen pro 12 různých výšek na Obr. A5 v apendixu. S nárůstem SPL lze pro oba pěvecké styly pozorovat podobné trendy. V oblasti kolem maxima kontaktu hlasivek s nárůstem SPL amplituda EGG pulsu narůstá, kdežto v oblasti před momentem kontaktu hlasivek a po momentu dekontaktu hlasivek amplituda EGG pulsu klesá. Odlišný trend lze pozorovat jen v nejhlubší poloze ve výšce c', kde popové zpěvačky zvýrazňují oblast pulzu v okolí dekontaktu hlasivek, kdežto klasické zpěvačky amplitudu snižují.

\section{Spektrální vlastnosti}

Hodnocení spektrálních vlastností bylo prováděno pomocí průměrovaných harmonických spekter. Protože je zásadní spektrální rozdíl dán typem vokálu, spektrální analýzy 
a porovnání byly prováděny samostatně pro jednotlivé vokály. V prvním řádku Obr. 4 lze vidět výsledky trojcestní analýzy rozptylu, kde je ukázán vliv žánru, výšky a dynamiky. U všech vokálo̊ se největší vliv žánru projevil ve spektrálním pásmu $5-6 \mathrm{kHz}$. Pro vokál A byla další maxima efektu žánru v pásmech 0 - $800 \mathrm{~Hz}$ a 1100 - $2100 \mathrm{~Hz}$. U vokálu I se maxima pohybovala mezi $1-2,2 \mathrm{kHz}$ a 2,4 - 3,4 kHz, u vokálu U mezi 2 - $4 \mathrm{kHz}$. Největší efekt výšky se ukazuje v oblastech 1 - $3 \mathrm{kHz}$ pro A, $500-2000 \mathrm{~Hz}$ pro I a 500 $3000 \mathrm{~Hz}$ pro U. Efekt dynamiky obecně dominuje (co se týče hladiny významnosti efektu) a jeho lokální maxima kopírují lokální maxima spekter popových zpěvaček.

Korelace harmonických spekter s výškou hlasu je zobrazena v druhém řádku. Velikost směrnice nárůstu spektra s narůstající výškou hlasu prozrazuje, které spektrální oblasti se nejvíce mění při změně výšky. Negativní směrnice se nachází v oblastech kolem a pod základní frekvencí a souvisí s jejím posunem. Lokální maxima směrnic se nacházejí blízko pozic lokálních minim průměrovaných spekter obou typů zpěvaček.

Korelace s SPL nevykazuje konkrétní charakteristická lokální maxima, ale u obou typů zpěvaček se globální maximum směrnice zesílení nachází mezi $3-5 \mathrm{kHz}$. U popových zpěvaček je toto maximum většinou ve vyšším pásmu než u klasických. Zelené tečkované čáry na grafech korelace s SPL prozrazují hladiny statistické významnosti rozdílu spekter

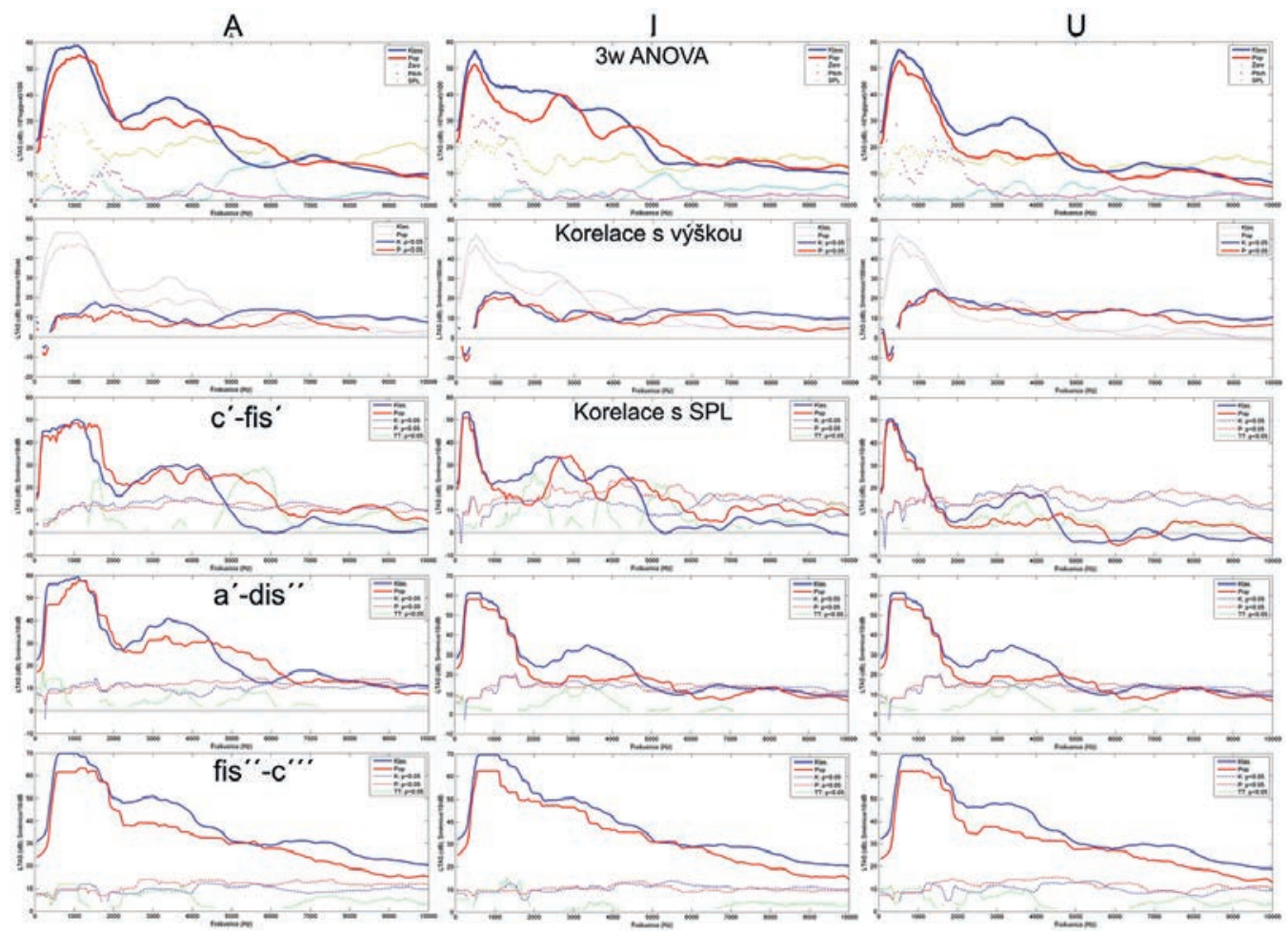

Obr. 4 Analýza průměrovaných harmonických spekter samostatně pro vokály A, I a U: trojcestná ANOVA (první řádek), korelace s výškou (druhý rádek), korelace s SPL pro výstřihy z uvedených rozsahů (spodní tři řádky). 
dle nepárového t-testu mezi typy zpěvaček. Nejvýznamnější rozdíly se nachází v hlubokých polohách (třetí řádek obrázku), a to v pásmu 4,5 - 6,5 kHz (u vokálu U mezi 3 - 4,5 kHz). Pro vyšší polohy se většinou tato maxima posouvají do hlubších částí spekter.

\section{Akustické parametry}

Vícenásobná analýza rozptylu prokázala, že všechny akustické parametry závisí na žánru, vokálu, výšce i SPL (viz Tab. A9 v apendixu). Jedinou výjimkou je parametr fullness, který nezávisí na vokálu. Pokud se podíváme na hodnoty hladin statistické významnosti, tak nejvýznamnější vliv žánru byl prokázán pro parametry rolloff $85 \%$, brightness $3000 \mathrm{~Hz}$, centroid a skewness. Typ vokálu ovlivňoval nejvíce hladinu první harmonické, rozdíl prvních dvou harmonických složek a oba pásmové centroidy. Výška hlasu měla silný vliv na téměř všechny parametry kromě rolloff $85 \%$, inharmonicity, fullness a activity. Intenzita hlasu nejvíce ovlivnila hladinu první harmonické, fullness a activity.

Při porovnání rozložení naměřených parametrů v hlasovém poli, lze lépe odhalit výškové a intenzitní rozdíly žánrů a vokálů. Porovnání žánrů pro různé vokály prokázalo, že standardní parametry [dHa1Ha2, L(H1), COG(2-5 kHz), COG(0-2.5 kHz)] ukazují odlišné trendy (viz Obr. A6 v apendixu), proto nejsou vhodné na odlišení stylů.

Naproti tomu parametry hodnotící celkové spektrální charakteristiky (globální) ukazují systematicky podobné rozdíly mezi žánry pro všechny typy vokálů (viz Obr. A7 a A8 v apendixu). Parametry rolloff $85 \%$, brightness $3000 \mathrm{~Hz}$ a centroid vykazují obecně vyšší hodnoty pro popové zpěvačky. V případě parametru entropie to platí jen v hluboké části výškového rozsahu. Parametry skewness, inharmonicity, fullness a activity zase v zásadě ukazují vyšší hodnoty u operních zpěvaček.

\section{Diskuse}

Měření rozsahových vlastnosti v této studii se zaměřuje jen na dvě oktávy, a tedy nereprezentuje fyziologické hlasové pole, a proto lze s odbornou literaturou porovnávat jen dynamické vlastnosti. Protože měření proběhlo v bezodrazové komoře (je to navazující studie k předchozímu porovnání vyzařovacích vlastnostî32) a bylo měřeno v nestandardní vzdálenosti $126 \mathrm{~cm}$ od úst, pro porovnání dynamických vlastností standardně měřených hlasových polí ve vzdálenosti $30 \mathrm{~cm}$ od úst je nutné k naměřeným hodnotám SPL přičíst cca $12.5 \mathrm{~dB}$. V takovém případě jsou zjištěná maxima SPL u vokálu A srovnatelná $\mathrm{s}$ předchozím měřením klasických zpěvaček ${ }^{33}$. Minimální hodnoty SPL pro $p$ dynamiku jsou však v předkládané studii výrazně vyšší než v uvedené studii, což potvrzuje, že $p$

32 FRIČ - PODZIMKOVÁ, op. cit.

33 FRIČ, Marek - KADLECOVÁ, A. Klára. Porovnání vlastností a parametrů hlasu pěvecky trénovaných a netrénovaných žen. Akustické listy, 2012, roč. 18, č. 2-3, s. 5-24. 
dynamika klasických zpěvaček je výrazně vyšší než minimální dynamika, která je součástí standardního měření fyziologického hlasového pole. Dynamický rozsah klasických zpěvaček z naměřených 4 dynamických úrovní je podobný dynamickému rozsahu profesionálních vystoupeni ${ }^{34}$, kde také nejtišší úrovně SPL leží relativně vysoko nad fyziologickým minimem.

Porovnání naměřených dynamických vlastností ukazují obecně vyšší dosahované SPL u klasických zpěvaček, které jsou statisticky významně vyšší v dvoučárkované oktávě a s narůstající výškou hlasu se postupně zvyšují. Podobné rozdíly maximálních dosahovaných SPL byly v této oktávě pozorovány při porovnání klasicky trénovaných a netrénovaných žen ${ }^{35}$. Popové zpěvačky však proti netrénované skupině dosahovaly mírně vyšších maxim SPL, zároveň ale byly srovnatelné se skupinou začínajících hereček ${ }^{36}$.

Opačný trend, kdy vyšší SPL dosahovaly popové zpěvačky, bylo možno pozorovat jenom u vokálu A v jednočárkované oktávě ve ff dynamice. Protože v této poloze a dynamice dosahovaly popové zpěvačky vyšších hodnot kontaktního koeficientu, lze předpokládat, že uvedený dynamický rozdíl byl způsobený odlišným vibračním mechanismem. Vyšší hodnoty CQ implikují více modální (hrudní) typ hlasu, resp. větší míru addukce, případně tlustší mod hlasivek v této výšce a dynamice, které jsou typické pro více řečový typ hlasu, jenž je charakteristický pro neklasické zpěvačky. ${ }^{37}$

I když se percepčního hodnocení škály Charakter zvuku zúčastnili jen tři posluchači, jejich vzájemná shoda byla velmi dobrá až výborná. Nejhorší byla u vokálu U, nejlepší u vokálu I. Shoda hodnotitelů byla podobná jako v předchozí studii hodnocení vokálợ ${ }^{38}$, a obecně vyšší než hodnocení delších úseků árie ${ }^{39}$. Proto lze konstatovat, že hodnocení charakteru zvuku nedělalo hodnotitelům problém a obecně se velmi dobře shodovali.

Slovní popis potvrdil, že percepčně nejvýznamnější vlastností odlišující operní a popový charakter zvuku je vibrato. Zpěv bez vibrata, resp. rovně, je typický pro popové zpěvačky a zpěv s vibratem až výrazným vibratem je typický pro operní styl. Základní barevná vlastnost, která odlišuje uvedené styly, světlý vs. tmavý, patří do první dimenze popisu hudebních zvukư ${ }^{40}$.

34 LAMARCHE A. - TERNSTROM S. - PABON P. The singer's voice range profile: female professional opera soloists, J Voice, 2010, roč. 24, č. 4, s. 410-426.

35 FRIČ - KADLECOVÁ, op. cit.

36 FRIČ, Marek. Porovnání parametrů hlasových poli mezi muži a ženami, Akustika, 2018, roč. 30, č. Sept., s. $42-63$.

37 MILLER op.cit; BARLOW - LOVETRI, op. cit.; BJÖRKNER, op. cit.; ECKLEY - SATALOFF et. al., op. cit.

38 FRIČ, Marek - BERTI, Alexandra - VOBĚRKOVÁ, Libuše. Percepční a vibro-akustické hodnocení změn tvaru vokálního traktu, Akustika, 2017, roč. 28, č. Sept., s. 37.

39 FRIČ, Marek - BERTI, Alexandra - OTČENÁŠEK, Jan. Percepční hodnocení vlastností pěveckého provedení koloraturní árie. Musicologica Brunensia, 2019, roč. 54, č.1, s. 187-222.

40 Studie ŠTĚPÁNEK, Jan - MORAVEC, Ondřej. Barva hudebniho zvuku a jeji slovní popis - Výsledky grantového projektu GAČR 202/02/1370. 1. vyd. Praha: Hudební fakulta Akademie múzických umění v Praze, 2005, s. 47. prokázala, že dimenze světlý, jasný - temný, tmavý vytváří protipóly první dimenze popisu barvy hudebních zvuků. 
Světlý charakter měly v zásadě popové zvuky a tmavý, temný, a dokonce zatmavený byl typický pro operní zvuky. Deskriptor tmavý je velmi často spojován s popisem klasického

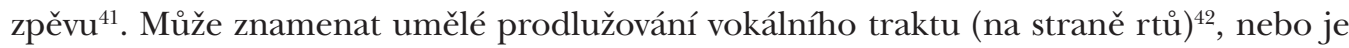
spojován s tzv. krytím. Světlé zvuky jsou v případě klasického zpěvu spíše přijímány v negativním smyslu, zejména pokud mají tzv. pronikavý charakter. V operním zpěvu je spíš preferován jasný typ zvuku ${ }^{43}$, který lze v př́ípadě „lesku“ spojovat i se změnou v následku hlasové reedukace ${ }^{44}$.

Trochu méně zásadní, ale významné, jsou deskriptory popového typu zvuku drsnost, slabší pěvecký formant, řečovost, ostrost, volnost a dyšnost (šum). Operní zvuky byly méně zásadním způsobem popisovány hlavovou barvou (tónem), přítomností (silnějším) pěveckého fromantu, plností a flétnovýcm charakterem. Uvedené vlastnosti jsou ve shodě s popisem dvou zásadních typů 'speech' a 'opera' kvalit dle Estill voice model ${ }^{45}$.

U vlastností tmavý vs. světlý je nutné zahrnovat fakt, že patří do skupiny často protichůdných popisů. Př́tomnost světlých a tmavých složek se ukázala jako nezávisláa ${ }^{46}$. To značí, že přítomnost tmavých složek nevylučuje zároveň přítomnost světlých. Při porovnání s výsledky předchozí studie je vhodné také uvažovat o tom, že tmavý a světlý charakter zvuku držených tónů nemusí být vyhodnocován ve stejném smyslu jako přítomnost tmavých a světlých složek zvuku v performačním provedení delšího celku.

Mezi nejvýznamněǰši zjištěné rozdíly mezi klasickými a popovými zpěvačkami patří odlišné kmitání hlasivek, dokumentováno na normalizovaných EGG pulsech. Odlišný charakter se týká zejména hlubší části měřeného rozsahu, dobře zachycen na Obr. A4. Ve výškách c' až a' je u popových zpěvaček dobře vidět větší šířka EGG pulzu, resp. jeho kontaktní fáze, která je podobná M1 mechanismu kmitư ${ }^{47}$, kdežto ve vyšších polohách se normalizované EGG pulsy klasických a popových zpěvaček relativně překrývají.

Statisticky nejvýznamnějš́i rozdíly se týkají způsobu změn kmitání hlasivek v závislosti na změně výšky, které jsou dokumentovány na Obr. 3 a mají protichůdný charakter v oblasti dekontaktní fáze kmitání hlasivek. Zatímco se u klasických zpěvaček s nárůstem výšky systematicky zvyšuje relativní amplituda kontaktu hlasivek, tedy kontakt hlasivek se prodlužuje vzhledem $\mathrm{k}$ délce cyklu, u popových zpěvaček je tento charakter odlišný. Tento výsledek implikuje, že zatímco klasické zpěvačky v měřeném rozsahu používaly M2 mechanismus a s nárůstem výšky jen zvyšovaly addukci hlasivek, popové zpěvačky nejhlubší polohy zpívaly v M1 a následně se kontaktní fáze, a tedy pravděpodobně i míra ad-

41 Přehled literatury o popisu vlastností operního zpěvu lze najít v FRIČ - BERTI - OTČENÁŠEK, op. cit.

42 GARNIER, Maeva - HENRICH, Nathalie - CASTELLENGO, Michele - SOTIROPOULO, David - DUBOIS, Daniele. Characterisation of Voice Quality in Western Lyrical Singing: from Teachers' Judgements to Acoustic Descriptions, Journal of Interdisciplinary Music Studies, 2008, roč. 1, č. 2, s. 62-91.

43 GARNIER - HENRICH - CASTELLENGO - SOTIROPOULO - DUBOIS, op. cit.

44 DVOŘÁKOVÁ, Eva - FRIČ, Marek. Efekt tréninku hlasu pomocí rezonančních cvičení brumenda u studentů - pilotní studie, Otorinolaryng. a Foniat. /Prague/. 2019, roč. 68, č. 2, s. 86-102.

45 STEINHAUER - MCDONALD KLIMEK - ESTILL op.cit.

46 FRIČ - BERTI - OTČENÁŠEK, op. cit.

47 ROUBEAU, B. - HENRICH, N. - CASTELLENGO, M. Laryngeal vibratory mechanisms: the notion of vocal register revisited. J Voice, 2009, roč. 23, č. 4, s. 425-38. 
dukce, zmenšovala. Menší kontaktní koeficient v hlubší poloze u operních zpěvaček lze vysvětlit i na základě efektu "tracheal pull” při hlubší poloze hrtanu. ${ }^{48}$ Avšak systematické změny EGG signálu v závislosti s nárůstem SPL byly vesměs podobné mezi jednotlivými typy zpěvaček, kromě nejhlubšího tónu c' (viz Obr. 3).

ANOVA průměrovaných spekter dobře dokumentuje variabilitu části spekter, které jsou významně ovlivněny sledovanými faktory. Nejvýznamněji mění spektrální hladiny celková SPL, její efekt je téměř rovnoměrný v celém frekvenčním rozsahu, ale maximální efekt lze pozorovat v oblastech pozic všech formantů. Gain faktor ${ }^{49}$, tedy směrnice nárůstu jednotlivých spektrálních pásem (činitel zesílení), v závislosti na změně SPL obecně nevykazuje nějakou specifickou strukturu. Průběhy spektrálních zesílení jsou podobné mezi typy zpěvaček. Výjimku tvoří jen v nejhlubší třetině měřeného rozsahu, kde globální maxima leží v blízkosti třetího a čtvrtého spektrálního vrcholu, mezi 3 - 4 kHz, což odpovídá naměřeným vrcholům gain faktoru profesionálních zpěváků a zpěvaček ve studiii ${ }^{50}$.

Výška hlasu ovlivňovala u vokálu A a U nejvýznamněji pásmo nad druhým formantem (1-3 kHz), zatímco u I jen pásmo do $2 \mathrm{kHz}$ (tedy nad prvním formantem). Spektrální zesílení bylo také nejvyšší v podobných oblastech, a protože neleží přímo na průměrných pozicích vokalických formantů, ale nad nimi, výsledek naznačuje systematický posun těchto formantových oblastí (resp. jejich rozšiřování) do vyšších frekvencí při nárůstu výšky.

Průměrovaná harmonická spektra dobře dokumentují vyšší polohu druhého až pátého spektrálního maxima u popových zpěvaček, což je v souladu s předchozími studiemi ${ }^{51}$. Na druhé straně klasické zpěvačky mají výrazně vyšší hladiny v nejhlubších částech spektra, což lze spojit s prohloubením pozice prvního formantu a posílením první harmonické složky. Tento efekt byl spojován s charakterizací zpěvu klasických zpěvaček ${ }^{52}$ a popisem rezonance zpěváky ${ }^{53}$, charakterem hlavové barvy hlasu (head voice) ${ }^{54}$ a vjemem méně tlačeného způsobu tvorby hlasu ${ }^{55}$.

Vícenásobná ANOVA však jako zásadní spektrální pásmo odlišující klasické a popové

48 “Tracheal pull” je efekt, kdy je při hlubším bráničním nádechu stahována průdušnice a tím i snižována poloha hrtanu. Na kmitání hlasivek se tento efekt projeví snížením kontaktního koeficientu hlasivek a menší addukcí.

GUZMAN, Marco - LAUKKANEN, Anne-Maria - KRUPA, Petr - HORÁČEK, Jaromir - ŠVEC, Jan G. - GENEID, Ahmed. Vocal tract and glottal function during and after vocal exercising with resonance tube and straw. J Voice, 2013, roč. 27, č. 4, s. 523.e19-523.e34.; IWARSSON J - SUNDBERG J. Effects of lung volume on vertical larynx position during phonation. J Voice, 1998, roč. 12, č.2, s. 159-165; IWARSSON, J - THOMASSON, M - SUNDBERG, J. Effects of lung volume on the glottal voice source. J Voice. 1998; 12:424-433. Snížení adduktivních sil dokumentuje i THOMASSON, op. cit.

49 TERNSTRÖM, Sten. Long-time average spectrum characteristics of different choirs in different rooms. Speech, Music and HearingQuarterly Progress and Status Report 1989, roč. 30, č. 3, s. 15-31.

50 FRIČ, Marek. Efekt zvyšování hlasitosti na spektrální charakteristiky hlasu u různých typů použití hlasu a u různých skupin hlasových profesí. Akustické listy, 2011, roč. 17, č. 1-2, s. 19-25.

51 BJÖRKNER, op. cit.; BARLOW - LOVETRI, op. cit.

52 FRIČ, M. Hodnocení rezonance hlasu žen, In Nové trendy akustického spektra vedecký recenzovaný zbornik, Zvolen, Technická univerzita vo Zvolene, 2013, s. 73-88.

53 FRIČ, 2014 op.cit.

54 GARNIER. - HENRICH et al., op. cit.

55 BERGAN. - TITZE. - STORY, op. cit. 
zpěvačky ukázala oblast mezi 4,5 - $6 \mathrm{kHz}$, což je oblast, ve které se projeví výrazný pokles v spektru klasických zpěvaček a začíná obecně dominovat spektrum popových zpěvaček. Tato oblast poklesu spektra nad pátým formantem se ukázala jako zásadní pro odlišení klasických sopránových a mezzosopránovaných typů hlasu ${ }^{56}$.

Standardní akustické parametry [dHa1Ha2, L(H1), COG $(2-5 \mathrm{kHz}), \mathrm{COG}(0-2.5 \mathrm{kHz})]$ jsou významně citlivé na vzájemnou polohu harmonických složek a formantů. Nacházíli se první harmonická pod prvním formantem, je méně zesílená a druhá harmonická složka může dosahovat vy̌ších hladin (jejich rozdíl je pak záporný). V př́padě, že je první harmonická těsně pod pozicí prvního formantu, je efekt vokálního traktu na proudění přes hlasivky výrazně posilující, v následku čehož je posílená i první harmonická složka. Uplatňuje se inertivní efekt vokálního traktu a hlas se tvoří zlehka ${ }^{57}$. Tento jev byl dobře dokumentován u dHa1Ha2, L(H1) u vokálu A, kde operní zpěvačky využily tento efekt výrazněji, a tedy lépe posílily hladinu první harmonické složky téměř v celém rozsahu. Pravděpodobně proto hlas působil více hlavovým způsobem ${ }^{58}$. Naproti tomu nižší hladina první harmonické složky u popových zpěvaček by měla být př́ičinou barevně úzkého tónu ${ }^{59}$ a lze ji spojovat i s tlačeným charakterem. ${ }^{60}$

Vyšší poloha spektrálního centroidu ve významném pásmu $2-5 \mathrm{kHz} u$ popových zpěvaček se projevila jen u vokálu A a U. Tento efekt dokumentuje zastoupení spektrální energie popových zpěvaček do vyšších pásem, dokonce výše, než je sopránový trend dle typů operních hlasů ${ }^{61}$. Odlišné trendy porovnání i centroidu hlubší části spektra $(0-2,5 \mathrm{kHz})$ prozrazují výrazně odlišný způsob nastavení vokálního traktu mezi uvedenými typy zpěvaček, který však nelze trendově jednoduše popsat. Vysoká poloha hlasu zpěvaček v naší studii neumožňovala použít přímý odhad poloh formantů pomocí LPC analýzy ${ }^{62}$. Proto dle našich výsledků, se lze domnívat, že vokály A a U zachovávají u klasických zpěvaček hlubší polohu prvních dvou formantů, kdežto u vokálu I mají nižší jen polohu druhého fromantu.

$\mathrm{Z}$ důvodu citlivosti standardních akustických parametrů na pozice prvních dvou (vokalických) formantů, nelze očekávat podobné trendy porovnání pro všechny vokály, a tedy takové parametry nejsou obecně vhodné pro porovnávání operního a popového stylu.

Globální spektrální parametry (rolloff $85 \%$, brightness $3000 \mathrm{~Hz}$, centroid, inharmonicity, skewness, entropie a fullness) se využívají při analýze hudebních nahrávek metodou

56 FRIČ, Marek - PAVLECHOVÁ, Angelika. Listening evaluation and classification of female singing voice categories, Logopedics Phoniatrics Vocology, 2020, roč. 45, č. 3, s. 97-109.

57 TITZE, I. R. A theoretical study of F0-F1 interaction with application to resonant speaking and singing voice, J Voice, 2004, roč. 18, č. 3, s. 292-298.

58 FRIČ, op. cit., 2013; FRIČ, op. cit., 2014.

59 ŠTĚPÁNEK, J. Perception of sharpness and narrowness in violin tones: influence of spectral components with changing pitch. In 8. mezinárodni kolokvium "Acoustics Zvolen 2004". 8. - 10. september 2004. Zvolen..

60 BERGAN. - TITZE. - STORY, op. cit.

61 FRIČ - PAVLECHOVÁ, op. cit.

62 Linear predictive Coding jako jedna ze základních metod odhadu pozic formantů selhává při výškách nad $350 \mathrm{~Hz}$ (f') UHLÍr, J. - SOVKA, P - POLLAK, P. - HANŽL, P. - ČMEJLA, R. Technologie hlasových komunikací. Praha: Nakladatelství ČVUT, 2007. 
Music Information Retrieval (dále MIR) ${ }^{63}$. Jedním z typických úkolů, při kterých se metoda MIR využívá, je analýza hlasu za účelem rozpoznání jazyka, či analýza hlasu nebo zpěvu za účelem rozpoznání emoce ${ }^{64}$. Parametry rolloff $85 \%$, brightness $3000 \mathrm{~Hz}$, centroid prokázaly dosah spektrální energie do vyšších frekvenčních částí (až nad hranici $5 \mathrm{kHz}$ ) u popových zpěvaček. Na druhé straně skewness ukazuje, že výraznější naklonění spektra vpravo od centroidu je patrné u klasických zpěvaček. Tento jev lze jednoduše vysvětlit formováním spektrálně užšího klastru vyšších formantů (F3-F5) u klasických zpěvaček proti širokému pásmu u popových. Tento jev připomíná klastrování těchto formantů u mužských operních hlasů v jeden pěvecký formant, ale dle dokumentace na harmonických spektrech, lze vidět, že u žen se tyto formanty nespojí v jeden. Jejich přiblížení způsobí posílení energie v pásmu $2-4 \mathrm{kHz}$ a tedy i následnou zvonivou barvu ${ }^{65}$. Vyšší hodnoty inharmonicity, fullness a activity u klasických zpěvaček lze vysvětlit zejména vyšší mírou fluktuace spekter v meziharmonickém prostoru, který je u nich primárně dán vyšší mírou výškové a intenzitní modulace hlasu (vibratem).

Většina akustických parametrů prokazovala u obou typů zpěvaček výrazné změny hodnot při přechodu nad c'”. Dle hodnot CQ lze tvrdit, že v této části přichází u popových zpěvaček ke změně vibračního mechanismu z M1 na M2, zatímco u klasických zpěvaček se kontakt hlasivek posílí a dle brightness $3000 \mathrm{~Hz}$ klesne energie nad $3 \mathrm{kHz}$. Souběžně s posílením první harmonické složky je výsledkem zejména barevná změna s více flétnovým charakterem. Udržení M2 mechanismu při ladění prvního formantu s první harmonickou složkou popisovali Garnier a kol. ${ }^{66}$ jako podklad full head rejstř́ku v dvoučárkované oktávě, typický pro lyrické a dramatické soprány.

Naše pozorování potvrdila, že globální parametry lze využít i k charakteristice pěveckých žánrů, protože jejich hodnocení všech vokálů je konzistentnější.

Dle Estill voice model ${ }^{67}$ je tmavší barva operních zvuků spojována s hlubší polohou hrtanu a distribucí akustické energie v hlubší části spektra než u popových zvuků. Výraznější hlavová barva klasických zpěvaček vzniká v důsledku ztenšení hlasivek a nakloněním štítné chrupavky, což je spojováno jak s posílením první harmonické složky, tak s tvorbou vibrata. Naproti tomu popové zpěvačky tvoří hlas blíže neutrálnímu řečovému nastavení hlasového systému. Zpívají s vyšší polohou hrtanu, použitím tlustších hlasivek, a na tvorbě šumu se může podílet výraznější přiblížení nepravých hlasivek.

63 KNEES P. - SCHEDL M. Music Similarity and Retrieval: An Introduction to Audio- and Web- based Strategies. Springer, 2016, 41-49.

64 LERCH A. An Introduction to Audio Content Analysis: Application in Signal Processing and Music Informatics. IEEE Press, 2012, s. 158-160.

65 Zvonivá barva (ringing voice quality) je spojována s nárůstem energie v pásmu $2-4 \mathrm{kHz}$, typický pro mužské operní pěvce a tvorbu pěveckého formantu. Viz OATES, M. Jennifer - BAIN, Belinda - DAVIS, Pamela - CHAPMA, Janice - KENNY Dianna. Development of an auditory-perceptual rating instrument for the operatic singing voice, J Voice, 2006, roč. 20, č. 1, s. 71-81.; WAPNICK, Joel - EKHOLM, Elizabeth. Expert consensus in solo voice performance evaluation, J Voice, 1997, roč. 11, č. 4, s. 429-436.

66 GARNIER, 2012 et al., op. cit.

67 STEINHAUER - MCDONALD KLIMEK - ESTILL, op. cit. 


\section{Závěry}

V předkládané práci byly porovnávány percepční, akustické a elektroglotografické vlastnosti hlasu mezi šesti operními a pěti popovými zpěvačkami. Analyzovány byly výstř̌ihy délky $0.5 \mathrm{~s}$ při zpěvu stupnic v rozsahu $\mathrm{c}^{\prime}-\mathrm{c}^{\prime}$ ' ve 4 dynamikách u vokálů $\mathrm{A}$, I a U a následně ve 4 polohách na oktávu při postupné gradaci hlasitosti. Poslechové hodnocení prokázalo zásadní rozdíl ve vjemu výraznějšího vibrata a tmavého nebo zatmaveného barevného charakteru operních zvuků, naproti tomu světlý charakter a rovný tón bez vibrata byl typický pro popové zvuky. Separátně byly popsány i vedlejší charakteristické vlastnosti. Způsob modulace hlasu v zásadě odlišoval styly. U operních zpěvaček zejména dominoval rozsah výškové modulace (v nejvyšších polohách dosahoval až 2 půltónů). Popové zpěvačky měly vyšší míru periodické nepravidelnosti a také vyšší frekvenci výškové modulace. Klasické zpěvačky dosahovaly obecně vyšších maxim SPL v dvoučárkované oktávě, popové měly vyšší maxima SPL jen u vokálu A uprostřed jednočárkované oktávy.

Elektroglotografie prokázala odlišný způsob fonačních nastavení mezi typy zpěvaček. Nejvýznamnější rozdíl se týkal střední a hlasité dynamiky v téměř 1,5 oktávě, v níž popové zpěvačky tvořily hlas s vyššími hodnotami kontaktního koeficientu. Navíc se prokázal systematický rozdíl změn tvaru EGG pulsů s nárůstem výšky hlasu, kde popové zpěvačky postupně redukovaly amplitudy EGG v oblasti dekontaktu hlasivek. Klasické zpěvačky však postupně zvyšovaly relativní amplitudy EGG pulsů v téže oblasti. Spektrální analýza prokázala zásadní rozdíly zejména v hlubších částech rozsahu, kde klasické zpěvačky obohacovaly zejména oblast 2-5 kHz mírným přibližením pozic třetího až pátého formantu, kdežto popové zpěvačky měly významně více energie ve vyšších spektrálních pásmech. Akustické parametry prokázaly dosah akustické energie do vy̌̌ších pásem u popových zpěvaček, ale zato s menším posílením pásma typického pro operní zpěv. Pro akustické odlišení operního a popového zpěvu se nejvíce uplatnily globální spektrální parametry, zejména ty, které nejsou ovlivněné pozici vokalických formantů. Tmavší barvu operních zvuků lze vysvětlit obecně hlubší polohou hrtanu, čímž se posilí první harmonická složka. Společně $\mathrm{s}$ tenčími hlasivkami (menším kontaktem hlasivek) se posílí vjem hlavové barvy a také lépe funguje inertivní efekt vokálního traktu, posilující oscilace celého hlasového systému. Zachování M2 mechanismu až do nejvyšší polohy společně s využitím ladění prvního formantu s první harmonickou umožňuje klasickým zpěvačkam nad c" přejít do full head rejstř́íku.

Naproti tomu popové zpěvačky tvoří hlas blíže neutrálnímu řečovému nastavení hlasového systému. Zpívají s vyšší polohou hrtanu, použitím tlustších hlasivek (větším kontaktem), a v hlase lze často slyšet i šumovou příměs. 


\section{Poděkování}

Tato studie vznikla na Akademii múzických uměnív Praze v rámci projektu „Porovnání různých pěveckých technik a stylü, problematika terminologie a procesů tvorby hlasu“ podpořeného z prostředků účelové podpory na specifický vysokoškolský výzkum, kterou poskytlo MŠMT v roce 2020.

\section{Bibliography}

ALLURI, V. - TOIVIAINEN, P. Exploring perceptual and acoustic correlates of polyphonic timbre. Music Perception, 2010, roč. 27, č. 3, s. 223-241.

ALLURI, V. - TOIVIAINEN, P. - JÄÄSKELÄINEN, I. - SAMS, M. - GLEREAN, E. - BRATTICO, E. Large-scale brain networks emerge from dynamic processing of musical timbre, key and rhythm. Neuroimage, 2012, roč. 59, s. 3677-3689.

BARLOW, C. - LOVETRI, J. Closed quotient and spectral measures of female adolescent singers in different singing styles. J Voice, 2010, roč. 24, č. 3, s. 314-318.

BERGAN, C. C. - TITZE, I. R. - STORY, B. The perception of two vocal qualities in a synthesized vocal utterance: ring and pressed voice. J Voice, 2004, roč. 18, č. 3, s. 305-317.

BESTEBREURTJE, M. E. - SCHUTTE, H. K. Resonance strategies for the belting style: results of a single female subject study. J Voice, 2000, roč. 14, č. 2, s. 194-204.

BJÖRKNER, E. Musical theater and opera singing-why so different? A study of subglottal pressure, voice source, and formant frequency characteristics.J Voice, 2008, roč. 22, č. 5, s. 533-540.

BOERSMA P. - KOVACIC G. Spectral characteristics of three styles of Croatian folk singing, $J$ Acoust Soc Am, 2006, roč. 119, č. 3, s. 1805-1816.

BOURNE T. - GARNIER M. Physiological and acoustic characteristics of the female Music Theater voice, J Acoust Soc Am, 2012, roč. 131, č. 2, s. 1586-1594.

DROMEY, Christopher - CARTER, Neisha - HOPKIN, Arden. Vibrato Rate Adjustment y Journal of Voice, 2003, roč. 17, č. 2, s. 168-178.

DVOŘÁKOVÁ, Eva - FRIČ, Marek. Efekt tréninku hlasu pomocí rezonančních cvičení brumenda u studentů - pilotní studie, Otorinolaryng. a Foniat. /Prague/. 2019, roč. 68, č. 2, s. 86-102.

ECKLEY, C. A. - SATALOFF, R. T. - HAWKSHAW, M. - SPIEGEL, J. R. - MANDEL, S. Voice range in superior laryngeal nerve paresis and paralysis, J Voice, 1998, roč. 12, č. 3, s. 340-348.

FRIČ, Marek a Iva PODZIMKOVÁ. Comparison of sound radiation between classical and pop singers. Biomedical Signal Processing and Control [online]. 2021, roč. 66 [cit. 2021-09-01]. Dostupné z: doi:10.1016/j.bspc.2021.102426.

FRIČ, Marek - PAVLECHOVÁ, Angelika. Listening evaluation and classification of female singing voice categories. Logopedics Phoniatrics Vocology, 2020, roč. 45, č. 3, s. 97-109.

FRIČ, Marek - BERTI, Alexandra - OTČENÁŠEK, Jan. Percepční hodnocení vlastností pěveckého provedení koloraturní árie. Musicologica Brunensia, 2019, roč. 54, č. 1, s. 187-222.

FRIČ, Marek. Porovnání parametrů hlasových poli mezi muži a ženami, Akustika, 2018, roč. 30, č. 2, s. 42-63.

FRIČ, Marek - BERTI, Alexandra - VOBĚRKOVÁ, Libuše. Percepční a vibro-akustické hodnocení změn tvaru vokálního traktu, Akustika, 2017, roč. 28, č. 2, s. 33-43.

FRIČ, M. Efekt změny tvaru vokálního traktu na vibro-akustické vlastnosti hlasu. In Nové trendy akustického spektra 2017, Technická univerzita vo Zvolene, 2017, s. 35-53.

FRIČ, Marek. Strategie poslechového hodnocení rezonance hlasu. In Nové trendy akustického spektra 
- vedecký recenzovaný zbornik, Zvolen: Material - Acoustics - Place, 2014, s. 73-80.

FRIČ, M. Hodnocení rezonance hlasu žen, In Nové trendy akustického spektra vedecký recenzovaný zbornik, Zvolen, Technická univerzita vo Zvolene, 2013, s. 73-88.

FRIČ, Marek - KADLECOVÁ A. Klára. Porovnání vlastností a parametrů hlasu pěvecky trénovaných a netrénovaných žen. Akustické listy, 2012. roč. 18, č. 2-3, s. 5-24.

FRIČ, Marek. Efekt zvyšování hlasitosti na spektrální charakteristiky hlasu u různých typů použití hlasu a u různých skupin hlasových profesí. Akustické listy, 2011, roč. 17, č. 1-2, s. 19-25.

GARNIER, M. - HENRICH, N. - CREVIER-BUCHMAN, L. - VINCENT, C. - SMITH, J. WOLFE, J. Glottal behavior in the high soprano range and the transition to the whistle register, J Acoust Soc Am, 2012, roč. 131, č. 1, s. 951-962.

GARNIER, Maeva - HENRICH, Nathalie - CASTELlENGO, Michele - SOTIROPOUlO, David - DUBOIS, Daniele. Characterisation of Voice Quality in Western Lyrical Singing: from Teachers' Judgements to Acoustic Descriptions, Journal of Interdisciplinary Music Studies, 2008, roč. 1, č. 2, s. 62-91.

HENRICH, N. - D'AlESSANDRO, C. - DOVAL, B. - CASTELlEGNO, M. On the use of the derivative of electroglottographic signals for characterization of nonpathological phonation. J Acoust Soc Am, 2004, roč. 115, č. 3, s. 1321-1332.

HERBST, C. T. - FITCH, W. T. - ŠVEC, J. G. Electroglottographic wavegrams: a technique for visualizing vocal fold dynamics noninvasively. J Acoust Soc Am, 2010, roč. 128, č. 5, s. 3070-3078.

KOCHIS-JENNINGS, K. A. - FINNEGAN, E. M. - HOFFMAN, H. T. - JAISWAL, S. Laryngeal muscle activity and vocal fold adduction during chest, chestmix, headmix, and head registers in females, J Voice, 2012, roč. 26, č. 2, s. 182-193.

KNEES, P. - SCHEDL, M. Music Similarity and Retrieval: An Introduction to Audio- and Web-based Strategies. Springer, 2016, s. 41-49.

KUČERA, M. - FRIČ, M. - FRITZLOVÁ, K. - HALÍř, M. Vokologie I: funkčni diagnostika a léćba hlasových poruch. Praha: Akademie múzických umění v Praze, 2019. ISBN 978-80-270-6200-3.

KULHÁNEK, Tomáš - FRIČ, Marek - OTČENÁŠEK, Jan. Software pro tvorbu percepčních testů na webovém rozhraní - software; MARC-Technologický list č́s. 82/16, Praha: MARC HAMU, 2016.

LAMARCHE A. - TERNSTROM S. - PABON P. The singer's voice range profile: female professional opera soloists, J Voice, 2010, roč. 24, č. 4, s. 410-426.

LARTILLOT, O. MIRtoolbox 1.7 User's Manual [online]. Oslo: University of Oslo, Department of Musicology, 2017. Dostupné z: https://www.jyu.fi/hytk/fi/laitokset/mutku/en/research/ materials/mirtoolbox/manual1-7.pdf.

LERCH, A. An Introduction to Audio Content Analysis: Application in Signal Processing and Music Informatics. IEEE Press, 2012, s. 158-160.

MILLER, D.G. Registers in Singing. Empirical and Systematic Studies in the Theory of the Singing Voice. Groningen, 2000. Disertační práce. University of Groningen.

NASIMITH, M. L. Toward a 21 century contemporary commercial music (CCM) singing pedagogy. In Pan-European Voice Congerence: Book of abstracts. Copenhagen: University of Copenhagen, 2019, s. 67-68. ISBN 978-87-971596-0-6.

OATES, M. Jennifer - BAIN, Belinda - DAVIS, Pamela - CHAPMA, Janice - KENNY Dianna. Development of an auditory-perceptual rating instrument for the operatic singing voice, J Voice, 2006, roč. 20, č. 1, s. 71-81.

ROUBEAU, B. - HENRICH, N. - CASTELLENGO, M. Laryngeal vibratory mechanisms: the notion of vocal register revisited. J Voice, 2009, roč. 23, č. 4, s. 425-38.

SADOLIN, K. Complete vocal technique. Copenhagen: Shout Publishing, 2000. 
STEINHAUER, K. - MCDONALD KLIMEK, M. - ESTILL, J. The Estill Voice Model: Theory E Translation Book. Pittsburgh, Pennsylvania: Estill Voice International, 2017. ISBN 978-0-9859023-0-8.

STONE, R. E., Jr. - CLEVELAND, T. F. - SUNDBERG, P. J. - PROKOP, J. Aerodynamic and acoustical measures of speech, operatic, and Broadway vocal styles in a professional female singer. $J$ Voice, 2003, roč. 17, č. 3, s. 283-297.

SUNDBERG, J. Articulatory interpretation of the „singing formant“, J Acoust Soc Am, 1974, roč. 55 , č. 4 , s. $838-844$.

SUNDBERG, J. The Science of Singing Voice. Illinois, 1989. Northern Illinois University Press.

ŠTĚPÁNEK, J. Perception of sharpness and narrowness in violin tones: influence of spectral components with changing pitch. In 8. mezinárodni kolokvium "Acoustics Zvolen 2004". 8.-10. september 2004. Zvolen.

ŠTĚPÁNEK, Jan - MORAVEC, Ondřej. Barva hudebniho zvuku a jeji slovni popis - Výsledky grantového projektu GAČR 202/02/1370. 1. vyd. Praha: Hudební fakulta Akademie múzických umění v Praze, 2005, s. 47.

TERNSTRÖM, Sten. Long-time average spectrum characteristics of different choirs in different rooms. Speech, Music and Hearing Quarterly Progress and Status Report 1989, roč. 30, č. 3, s. $15-31$.

TITZE, I. R. - WORLEY, A. S. - STORY, B. H. Source-vocal tract interaction in female operatic singing and theater belting. Journal of Singing, 2011, roč. 67, č. 5, s. 561-572.

TITZE, I. R. - WORLEY, A. S. Modeling source-filter interaction in belting and high-pitched operatic male singing. The Journal of the Acoustical Society of America, 2009, roč. 126, č. 3, s. 1530-1540.

TITZE, I. R. A theoretical study of F0-F1 interaction with application to resonant speaking and singing voice, J Voice, 2004, roč. 18, č. 3, s. 292-298.

THALEN, M. - SUNDBERG, J. Describing different styles of singing: a comparison of a female singer's voice source in „Classical“, „Pop“, „Jazz“ and „Blues“, Logoped Phoniatr Vocol, 2001, roč. 26, č. 2, s. 82-93.

THOMASSON, M. - SUNDBERG, J. Consistency of inhalatory breathing patterns in professional operatic singers, J Voice, 2001, roč. 15, č. 3, s. 373-383.

THOMASSON, M. Belly-in or belly-out? TMH-QPSR, 2003, roč. 45, č. 1, s. 61-73.

Universal voice: UV system [online]. [cit. 2020-02-19]. Dostupné z: https://universalvoice.nl/uv-system.

WAPNICK, Joel - EKHOLM, Elizabeth. Expert consensus in solo voice performance evaluation, J Voice, 1997, roč. 11, č. 4, s. 429-436. 


\section{Apendix}

\section{Doplněk metodické části}

\section{Záznam hlasu a elektroglotografie}

Nahrávání hlasových úkolů probíhalo v bezodrazové místnosti (kritická frekvence $125 \mathrm{~Hz}$ ISO $3475 ; 5,26 \times 3,75 \times 2,25 \mathrm{~m}$ ) pomocí kulového mikrofonu s tělem Sennheiser K6 a kapslí Sennheiser ME 62, který byl umístěn ve vzdálenosti 1,26 m od úst zpěvaček v azimutu $0^{\circ}$ a elevaci $0^{\circ}$.

Signál byl z mikrofonu přenesen analogově do předzesilovače SM Pro Audio PR8 a následně zaznamenán v rekordéru Tascam X-48 v bitové hloubce 24 bitů a při vzorkovací frekvenci $48 \mathrm{kHz}$.

Zpěvačky byly usazeny na stoličku v prostoru a jejich hlava byla fixována pomocí stojanu, nad nímž zpěvačky držely ústa. Během nahrávání vzorků byly zároveň sledovány dvěma kamerami (přední a postranní), aby nedošlo k posunu hlavy a k následnému vychýlení z osy s mikrofonem.

\section{Parametrizace akustického signálu}

Z celkových výstř̌ihů kvazistacionárních částí vokálů délky $500 \mathrm{~ms}$ byly z akustického signálu vypočteny průměrné hladiny $\mathrm{SPL}^{68}$ a výšky ${ }^{69}$ zvukủ, které reprezentovaly pozice výstřihů na mapě hlasového pole.

Vlastnosti modulace výšky a SPL (vibrato) celkových výstřihů byly vypočteny z jednotlivých výstřihů na segmentech délky $15 \mathrm{~ms}$ s posunem 5 ms. Výšková i SPL modulace byly hodnoceny parametry frekvence modulace, rozsah modulace, periodická (Jitter) a amplitudová (Shimmer) nepravidelnost modulace dle ${ }^{70}$.

Následně byla vypočtena spektra pomocí Fast Fourier Transformation (FFT), bylo použito okno typu Hanning. Pro další analýzu spekter byla použita transformovaná (harmonická) spektra, ve kterých celé pásmo konkrétní harmonické složky bylo nahrazeno průměrnou amplitudou tohoto pásma.

FFT vypočítala spektrum v celé šíři zaznamenaného frekvenčního pásma, z něhož byly vypočteny parametry:

- Hladina první harmonické - L(H1).

- Rozdíl hladin první a druhé harmonické složky akustického spektra - dHa1Ha2.

68 Hodnoty SPL byly vypočteny na základě hodnot RMS vztažených k hladinám RMS kalibračního signálu měřeného při frekvenci 1 kHz a SPL 94 dB kalibrátorem MVI technologies Cal 01.

69 Základní frekvence byla stanovena dle prvního vrcholu grafu autokorelace, následně byla přepočtena na výšku (pitch) v midi tónech dle vztahu midi $=69+12 * \log \left(f_{d} / 440\right) / \log (2)$, kde f0=440 Hz (a') odpovídá hodnotě 69 midi. 70 DROMEY, Christopher - CARTER, Neisha - HOPKIN, Arden. Vibrato Rate Adjustment. Journal of Voice, 2003, roč. 17 , č. 2 , s. $168-178$. 
- Spektrální centroid pásma 2-5 kHz - COG(2-5 kHz).

- Spektrální centroid pásma prvních 2 formantů $(0-2.5 \mathrm{kHz})$ - COG(0-2.5 kHz).

- Rolloff $85 \%$ - frekvence, pod kterou se nachází $85 \%$ energie spektra ${ }^{71}$.

- Brightness $3000 \mathrm{~Hz}$ - množství energie spektra, které se nachází nad hranicí $3000 \mathrm{~Hz}$.

- Centroid a skewness - statistické centrální momenty, které charakterizují rozdělení dané náhodné veličiny. Centroid se také nazývá těžiště, geometrický střed nebo míra centrální tendence, jedná se o první centrální moment. Šikmost je třetí centrální moment. Nabývá-li pozitivních hodnot, obsahuje pravá strana spektra (od těžiště) hodnoty převyšující střední hodnotu. Dosahuje-li záporných hodnot, obsahuje levá strana spektra hodnoty převyšující střední hodnotu. ${ }^{72}$

- Inharmonicity - množství vyšších frekvenčních složek, které nespadají do harmonické řady základního tónu. Parametr je vyjádřen v hodnotách 0 až 1 . Základní tón je zjištěn pomocí autokorelace. ${ }^{73}$

- Entropie - vyjadřuje relativní shannonovskou (informační) entropii vstupního signálu čili střední hodnotu množství informace obsažené ve spektru. Pokud entropie dosahuje vyšších hodnot, pravděpodobnostní funkce daného spektra je spíše plochá a je zde tedy vysoká informační nejistota. Pokud má entropie nižší hodnoty, pravděpodobnostní funkce daného spektra vykazuje jeden jasný vrchol a informační nejistota je nízká. Entropie tedy poskytuje obecné vyjádření, zda pravděpodobnostní funkce spektra signálu (vstup) obsahuje jasně dané vrcholy nebo je spíše plochá. ${ }^{74}$

- Fullness a activity - oba parametry vyjadřují rozdíly mezi spektry po sobě jdoucích framů. Konkrétně je porovnávána výkonová spektrální hustota (popisuje výkon jednotlivých spektrálních složek) předchozího a následujícího framu. Jeden frame má délku 25 ms. Někdy je toto porovnání nazýváno jako spectral flux. Ze získaných hodnot je dále počítán průměr. Fullness vyjadřuje výše popsaný rozdíl spekter v pásmu $50 \mathrm{~Hz}-200 \mathrm{~Hz}$, activity v pásmu $1600 \mathrm{~Hz}-6400 \mathrm{~Hz}{ }^{75}$

\section{Parametrizace elektroglotografického signálu}

Elektroglotografický signál byl pořízen pomocí přístroje Laryngograph ${ }^{\circledR}$ D-200, elektrody byly umístěny na krk ve výšce hlasivek v oblasti středu jejich lemů (křídel) štítné chrupavky.

71 LARTILLOT, O. MIRtoolbox 1.7 User's Manual [online]. Oslo: University of Oslo, Department of Musicology, 2017. Dostupné z: https://www.jyu.fi/hytk/fi/laitokset/mutku/en/research/materials/mirtoolbox/ manual1-7.pdf.

72 LARTILLOT, op. cit.

73 LARTILLOT, op. cit.

74 LARTILLOT, op. cit.

75 ALLURI, V. - TOIVIAINEN, P. Exploring perceptual and acoustic correlates of polyphonic timbre. Music Perception, 2010, roč. 27, č. 3, s. 223-241; ALLURI, V. - TOIVIAINEN, P. - JÄÄSKELÄINEN, I. - SAMS, M. - GLEREAN, E. - BRATTICO, E. Large-scale brain networks emerge from dynamic processing of musical timbre, key and rhythm. Neuroimage, 2012, roč. 59, s. 3677-3689. 
Signál byl zaznamenán do jednoho z kanálů Tascam X-48 se stejným nastavením jako u zvukového signálu.

Elektroglotografický signál jednotlivých výstřihů byly v oknech se šíŕkou $50 \mathrm{~ms}$ a posunem $10 \mathrm{~ms}$ na základě upraveného algoritmu pro výpočet EGG wavegramü76 vytvořeny průměrné normalizované periody kmitáni ${ }^{77}$. Fázi $20 \%$ délky cyklu př́ílušela hodnota maxima první derivace EGG signálu (DEGG) a délka periody byla stanovena na základě autokorelace EGG signálu. Takto určené periody byly amplitudově normalizovány na hodnoty mezi $0-1$ a časově převzorkovány tak, že délka periody odpovídá 200 vzorkům.

Z normalizovaných period EGG signálů byly na základě vzdálenosti kladného a záporného vrcholu první derivace vypočteny hodnoty kontaktního koeficientu (CQd) ${ }^{78}$.

\section{Poslechový test}

Hodnocení vlastností hlasu proběhlo samostatně pro všechny tři vokály v poslechových testech připravených v prostředí PsychotestEditor ${ }^{79}$.

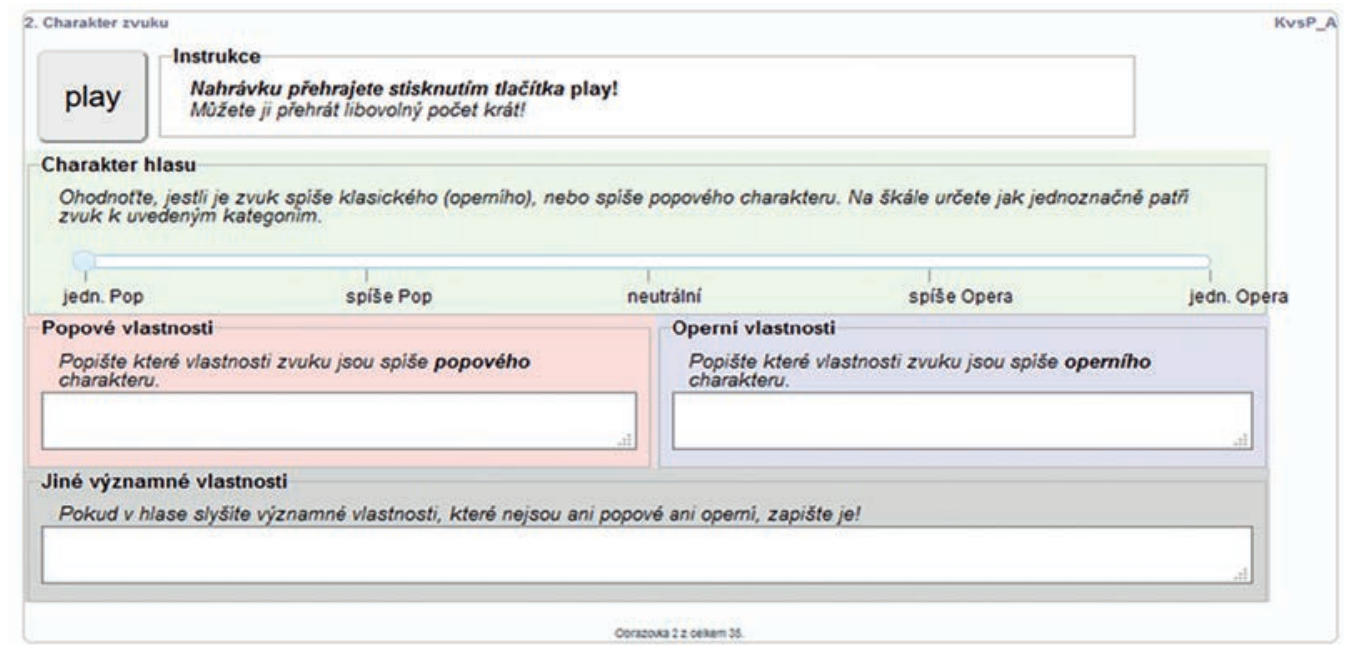

Obr. A1 Grafické rozhraní poslechového testu.

76 HERBST - FITCH - ŠVEC, op. cit.

77 více viz FRIČ, M. Efekt změny tvaru vokálního traktu na vibro-akustické vlastnosti hlasu. In Nové trendy akustického spektra 2017, Technická univerzita vo Zvolene, 2017, s. 35-53.

78 HENRICH, N. - D'ALESSANDRO, C. - DOVAL, B. - CASTELLEGNO, M. On the use of the derivative of electroglottographic signals for characterization of nonpathological phonation. J Acoust Soc Am, 2004, roč. 115, č. 3, s. 1321-1332.

79 KULHÁNEK, Tomáš - FRIČ, Marek - OTČENÁŠEK, Jan. Software pro tvorbu percepčních testů na webovém rozhraní - software; MARC-Technologický list čis. 82/16, Praha: MARC HAMU, 2016. 
Hodnocení a slovní popis stimulů provedli všichni tři autoři článku, jejich vzájemná shoda byla hodnocena pomocí parametru Cronbachova alfa. Zpracování slovních popisů byl proveden zvlášt pro každý vokál. Ze slovních popisů byly vytvořeny četnostní slovníky ${ }^{80}$ a vybrány nejčastěji se vyskytující atributy popisu samostatně pro popový a operní charakter zvuku.

\section{Statistické zpracování výsledků}

Porovnání hodnot SPL a CQd bylo provedeno pomocí nepárového t-testu samostatně pro všechny vokály a samostatně pro jednotlivé dynamiky zpěvu stupnic a postupného zesilování. Pro každý úkol a vokál byly porovnány průměrné hodnoty SPL všech výstřihů, které spadaly do intervalů se šířkou 2 půltónů v celém měřeném dvouoktávovém rozsahu výšky.

Akustické a vibrační parametry, jakož i průměrované reprezentanty průběhů period cyklů EGG signálu, podobně jako harmonických spekter jednotlivých segmentů, byly podkladem pro porovnání pomocí vícenásobné analýzy rozptylu (ANOVA), kde jednotlivé faktory byly reprezentovány žánrem, výškou, změřenou SPL a typem vokálu. U EGG cyklů byly porovnávány hodnoty amplitud jednotlivých fází periody (segmentovány na 200 bodů), u spekter hladiny jednotlivých spektrálních pásem (segmentovány na 200 pásem). Pro hodnocení lineárního trendu změn normalizovaných EGG period a harmonických spekter byla použita lineární regrese a korelační analýza s naměřenou výškou, resp SPL. Do úvahy byly vzaty jenom hodnoty směrnice lineárního trendu, kde korelační koeficient vyšel s hladinou statistické významnosti menší než 0,05 .

\section{Detaily výsledkové části}

\section{Poslechové testy}

Tab. A1 Shoda hodnotitelů na škále charakter zvuku (popový vs operní) vyjádřená pomocí Cronbachovy alfy ${ }^{81}$.

\begin{tabular}{|l|c|c|c|}
\hline Vokál & A & I & U \\
\hline Cronbachova alfa & 0.9167 & 0.9363 & 0.8469 \\
\hline
\end{tabular}

80 V programu SlovniPopis vytvořeném prvním autorem sdělení v prostředí MATLAB, který umožňuje vytvářet četnostní slovníky, spojovat slova a výrazy se stejným výrazem a následně sleduje četnost výskytu jednotlivých atributů mezi hodnotiteli i v popisech jednotlivých stimulů.

81 Cronbachova alfa (CA) je hodnocena jako velmi dobrá $(\mathrm{CA}>0,8)$ a jako výborná $(\mathrm{CA}>0,9)$. 
Tab. A2 Charakteristické vlastnosti popových zvuků.

\begin{tabular}{|l|r|r|r|r|l|}
\hline $\begin{array}{l}\text { Popové- } \\
\text { vlastnosti }\end{array}$ & SUM & \multicolumn{1}{|c|}{ A } & \multicolumn{1}{|c|}{ I } & U & \\
\hline $\begin{array}{l}\text { (bez ) vib- } \\
\text { rata }\end{array}$ & $\mathbf{8 9}$ & 27 & 39 & 23 & $\begin{array}{l}\text { bez vibrata, malé vibrato, nepravidelné vibrato, mírné vibrato, } \\
\text { slabší vibrato, minimální vibrato }\end{array}$ \\
\hline rovné & $\mathbf{5 6}$ & 17 & $\mathbf{6}$ & 33 & téměř rovný hlas, rovný hlas bez vibrací, rovné - ploché, rovné \\
\hline světlé & $\mathbf{5 1}$ & 13 & 21 & 17 & $\begin{array}{l}\text { světlé-jasné, světlé-vybledlé, světlé, světlejšího charakteru, svět- } \\
\text { lost, světlejší, světlý hlas }\end{array}$ \\
\hline drsnost & $\mathbf{2 9}$ & 7 & 11 & 11 & hlasová drsnost, diplofonie, mírná drsnost, drsné \\
\hline $\begin{array}{l}\text { (slabší } \\
\text { pěvecký) } \\
\text { formant }\end{array}$ & $\mathbf{3 4}$ & 10 & 7 & 17 & $\begin{array}{l}\text { nepríliš silný pěvecký formant, bez slyšitelného pěveckého for- } \\
\text { mantu, bez silného formantu, bez slyšitelných formantů, slabší } \\
\text { formant }\end{array}$ \\
\hline řečové & $\mathbf{3 2}$ & 7 & 12 & 13 & řečový charakter, řečového charakteru, řečového charakteru \\
\hline neopřené & $\mathbf{2 8}$ & 12 & 10 & 6 & málo opřené, bez opory, neopřené, malé opření \\
\hline jasné & $\mathbf{2 6}$ & 10 & 9 & 7 & jasné-světlé, jasné, \\
\hline ostré & $\mathbf{2 5}$ & 5 & 12 & 8 & ostrost, ostré, ostrý hlas, ostrá barva \\
\hline volné & $\mathbf{2 2}$ & 5 & 10 & 7 & volné \\
\hline dyšné & $\mathbf{1 9}$ & 5 & 7 & 7 & dyšné, mírně dyšné, šum, šelest \\
\hline
\end{tabular}

Tab. A3 Charakteristické vlastnosti operních zvuků.

\begin{tabular}{|l|r|r|r|r|l|}
\hline $\begin{array}{l}\text { Operní- } \\
\text { vlastnosti }\end{array}$ & SUM & \multicolumn{1}{|c|}{ A } & \multicolumn{1}{|c|}{ I } & \multicolumn{1}{c|}{ U } & \multicolumn{1}{|c|}{ Souhrn } \\
\hline vibrato & $\mathbf{1 2 8}$ & 48 & 44 & 36 & $\begin{array}{l}\text { vibrato, mohutné vibrato, operní vibrato, velké vibrato, náznak } \\
\text { vibrata, ohromné vib., silné vib., větší vibrato }\end{array}$ \\
\hline $\begin{array}{l}\text { tmavé / } \\
\text { temné }\end{array}$ & $\mathbf{7 7}$ & 24 & 34 & 19 & $\begin{array}{l}\text { snaha o tmavení, zatmavování, dotmavené, tmavené, temnější } \\
\text { barva, zatmavené, temná barva, temnější }\end{array}$ \\
\hline $\begin{array}{l}\text { hlavová } \\
\text { barva / tón }\end{array}$ & $\mathbf{5 9}$ & 18 & 21 & 20 & $\begin{array}{l}\text { mírná hlavová barva, hlavový tón, dost výrazný hlavový tón, hla- } \\
\text { vová barva }\end{array}$ \\
\hline $\begin{array}{l}\text { (pěvecký) } \\
\text { formant }\end{array}$ & $\mathbf{3 1}$ & 8 & 12 & 11 & $\begin{array}{l}\text { pěvecký formant, jasný pěvecký formant, silné formanty, slyši- } \\
\text { telný formant }\end{array}$ \\
\hline plnost & $\mathbf{2 3}$ & 14 & 0 & 9 & plnost, plnější hlas, zní plně, plný hlas \\
\hline flétnovost & $\mathbf{2 3}$ & 0 & 12 & 11 & flétnový charakter, flétnovost, flétnová barva \\
\hline
\end{tabular}


Tab. A4 Slovní popis neutrálních zvuků a zvuků neodpovídajících originálním stylům zpěvaček u vokálu $A$.

\begin{tabular}{|c|c|c|c|}
\hline Subj & $\mathbf{P}$ & Popové vlastnosti & Operní vlastnosti \\
\hline K1 & $c^{\prime}$ & & $\begin{array}{l}\text { vibrato, nízká krajní poloha zapříčiňuje méně } \\
\text { energie na vyšších frekvenčních složkách, hlas } \\
\text { zní ale plně a temněji, opatrný začátek, zatma- } \\
\text { vování, mírná hlava, snaha kultivovat }\end{array}$ \\
\hline K3 & $c^{\prime}$ & hlasový šelest & $\begin{array}{l}\text { v hlase je patrná vibrace, krajní poloha - méně } \\
\text { patrný formant, ale hlas zní plně, vibrato, sna- } \\
\text { ha o ztmavení barvy, zatmavené, nízka poloha } \\
\text { hrtnanu, kultivované (uměle) }\end{array}$ \\
\hline K3 & $a^{\prime}$ & drsné, neopřené, chybí fokus & $\begin{array}{l}\text { plný hlas, jasně slyšitelný pěvecký formant, } \\
\text { tmavené, vibrato, nestabilita výšky, mírná hla- } \\
\text { va, }\end{array}$ \\
\hline P5 & $a^{\prime}$ & $\begin{array}{l}\text { jasné, světlé, ostré, průzračné, není } \\
\text { kultivované, menší i opora, není jed- } \\
\text { noznačná hlavová barva }\end{array}$ & $\begin{array}{l}\text { operní vibrato, typický formant, plnější hlas, } \\
\text { vibrato (mírné), hlava je jen mírná, pocit sniže- } \\
\text { ní polohy hrtanu }\end{array}$ \\
\hline P1 & fis'" & $\begin{array}{l}\text { na vysokou polohu malé vibrato, chy- } \\
\text { bí plnost klasického zpěvu, flétnové, } \\
\text { světlé, jasné, bez vibrata, rovné }\end{array}$ & dost hlavy, trubice, thin (tenké hlasivky) \\
\hline K1 & $a^{\prime}$ & $\begin{array}{l}\text { nízká dynamika, nepřiliš silný pěvecký } \\
\text { formant, světlé, drsnost v hlase, mírný } \\
\text { šum, neúplná hlava - plochost }\end{array}$ & vibrato, jen mírná hlavová barva \\
\hline P3 & $a^{\prime}$ & $\begin{array}{l}\text { hlas nezní přiliš plný, jasné, světlé, není } \\
\text { kultivované }\end{array}$ & vibrato, celkem dost hlavové rezonance \\
\hline K2 & $c^{\prime}$ & $\begin{array}{l}\text { bez vibráta, slabé formanty, málo } \\
\text { energie ve vyšších harmonických, rov- } \\
\text { né, volné, ploché }\end{array}$ & tmavené, mírně zatmavené \\
\hline K5 & $a^{\prime}$ & $\begin{array}{l}\text { hlas je téměř rovný, patrný pěvecký } \\
\text { formant do } 5 \mathrm{kHz} \text {, bez vibrata, málo } \\
\text { opřené }\end{array}$ & $\begin{array}{l}\text { tmavené, dost hlavové barvy, náznak rozvib- } \\
\text { rování }\end{array}$ \\
\hline K5 & fis'" & $\begin{array}{l}\text { hlasu chybí typický operní formant } \\
\text { i silné vibrato, bez vibrata, světlé, rov- } \\
\text { ný tón }\end{array}$ & $\begin{array}{l}\text { hlavová barva, trubice, rezonance, flétnový } \\
\text { charakter }\end{array}$ \\
\hline
\end{tabular}


Tab. A5 Slovní popis neutrálních zvuků a zvuků neodpovídajících originálním stylům zpěvaček u vokálu I.

\begin{tabular}{|c|c|c|c|}
\hline Subj & $\mathbf{P}$ & Popové vlastnosti & Operní vlastnosti \\
\hline K1 & $c^{\prime}$ & hrudní charakter, mírný šum a tlačení & $\begin{array}{l}\text { tmavené, náznak vibrata, pěvecký formant, } \\
\text { temnější barva, vibrato, hlavový zvuk }\end{array}$ \\
\hline K2 & fis' & světlé, málo vibrata, volné, málo opření & $\begin{array}{l}\text { silné vibrato, jasný pěvecký formant, flétnová } \\
\text { barva, operní nasazení, trubice }\end{array}$ \\
\hline K2 & $c^{\prime}$ & $\begin{array}{l}\text { náznak hrudní barvy, méně vyšších har- } \\
\text { monických, klidné, řečový charakter, volné }\end{array}$ & $\begin{array}{l}\text { tmavené, vibrato, temnější barva, relativně } \\
\text { dost hlavového tónu }\end{array}$ \\
\hline K5 & $a^{\prime}$ & menší vibrato, šum & $\begin{array}{l}\text { tmavené, silný pěvecký formant, temnější } \\
\text { barva, mírná hlava, mírně zatmavené (trubko- } \\
\text { vý odstín), mírné vibrato }\end{array}$ \\
\hline K1 & $a^{\prime}$ & $\begin{array}{l}\text { ostré, hrudní charakter, šum, drsnost, } \\
\text { malé vibrato }\end{array}$ & $\begin{array}{l}\text { tmavené, hlas je temnější, s vibratem a silněj- } \\
\text { ším pěveckým formantem, náznak hlavové } \\
\text { barvy }\end{array}$ \\
\hline K5 & $c^{\prime}$ & menší vibrato, šum, málo vibrata & $\begin{array}{l}\text { tmavené, silný pěvecký formant, temnější } \\
\text { barva, mírná hlava, mírně zatmavené (trubko- } \\
\text { vý odstín), mírné vibrato }\end{array}$ \\
\hline K1 & $a^{\prime}$ & $\begin{array}{l}\text { ostré, hrudní charakter, šum, drsnost, } \\
\text { malé vibrato }\end{array}$ & $\begin{array}{l}\text { vibrato, tmavené, hlas je temnější, s vibratem } \\
\text { a silnějším pěveckým formantem, náznak hla- } \\
\text { vové barvy a tmavení }\end{array}$ \\
\hline P2 & $c^{\prime}$ & $\begin{array}{l}\text { ostré, hrudní, jasné, méně prominentní } \\
\text { pěvecký formant, rečové, nekultivované, } \\
\text { nepravidelné vibrato-malé, bzukot - malá } \\
\text { drsnost, mírný tlak, }\end{array}$ & Vibrato, hlas je temnějšího charakteru \\
\hline P3 & fis"' & $\begin{array}{l}\text { světlé, ostré, rovné, bez vibrata, světlý } \\
\text { hlas, řečový charakter, šum a drsnost }\end{array}$ & $\begin{array}{l}\text { nejspíše hodně vyšších harmonických, ná- } \\
\text { znak hlavového tónu a flétnovosti }\end{array}$ \\
\hline K5 & fis' & $\begin{array}{l}\text { světlé, bez vibrata, flétnový charakter, } \\
\text { světlý vzdušný hlas, s minimálním vibra- } \\
\text { tem, málo vyšších harmonických, velmi } \\
\text { rovné na operu, volné, nevýrazná opora }\end{array}$ & dobrá hlavová barva a flétnovost \\
\hline
\end{tabular}


Tab. A6 U Slovní popis neutrálních zvuků a zvuků neodpovídajících originálním stylům zpěvaček u vokálu $U$.

\begin{tabular}{|c|c|c|c|}
\hline Subj & $\mathbf{P}$ & Popové vlastnosti & Operní vlastnosti \\
\hline K5 & fis" & $\begin{array}{l}\text { hlas je světlý a ostrý, méně vyšších harmo- } \\
\text { nických, mírné vibrato, volné }\end{array}$ & vibrato, flétnová a hlavová barva, trubice \\
\hline K6 & $a^{\prime}$ & $\begin{array}{l}\text { slabší vibrato, bez jasně slyšitelného forman- } \\
\text { tu, hlas působí vzdušně, rovné, malé vibrato, } \\
\text { volné }\end{array}$ & $\begin{array}{l}\text { tmavené, vibrato, operní nasazení, hlavová } \\
\text { barva, náznak flétnovosti }\end{array}$ \\
\hline K3 & $a^{\prime}$ & $\begin{array}{l}\text { světlejší, bez silných formantů, malé vibrato, } \\
\text { mírně řečové }\end{array}$ & větší vibrato, flétnovost, $M 2$ falsetto \\
\hline K1 & $c^{\prime}$ & nízká dynamika, malé opření & $\begin{array}{l}\text { velké vibrato, zatmavené, temná brava, mír- } \\
\text { ná hlavová barva, kultivované }\end{array}$ \\
\hline K5 & $c^{\prime}$ & $\begin{array}{l}\text { rovné, šelest, bez slyšitelných formantů, bez } \\
\text { vibrata, řečové, povolené }\end{array}$ & Výslovnost, náznak hlavy \\
\hline K3 & $c^{\prime}$ & $\begin{array}{l}\text { podivně rovné, bez silných formantů, řečové, } \\
\text { povolené, nestabilní, zav̌rené }\end{array}$ & tmavené \\
\hline P1 & fis" & světlé, jasné, rovné, bez vibrata & $\begin{array}{l}\text { hlas zní plně, s formantem, hlavová barva, } \\
\text { opřené, flétnové }\end{array}$ \\
\hline P2 & fis" & $\begin{array}{l}\text { flétnové, rovné, jasné, ostré, světlé, slabší } \\
\text { vibrato, šum a drsné }\end{array}$ & $\begin{array}{l}\text { plný hlas, slyšitelný formant, trubka, hlavo- } \\
\text { vá barva (mírná) }\end{array}$ \\
\hline P3 & fis" & $\begin{array}{l}\text { jasné, ostré, rovné, hlas je světlý, ale obsahu- } \\
\text { je silné vyšší harmonické složky, bez vibrata }\end{array}$ & hlavová barva, trubice \\
\hline K2 & $c^{\prime}$ & $\begin{array}{l}\text { jemnost, světlost, výslovnost, nízká dynami- } \\
\text { ka, bez silného formantu, povolené, řečové, } \\
\text { rovné }\end{array}$ & \\
\hline K5 & $a^{\prime}$ & $\begin{array}{l}\text { bez vibrata, slabší formant, povolené, rovné, } \\
\text { bez opory, řečové }\end{array}$ & vibrato, výslovnost, mohutnost \\
\hline
\end{tabular}

\section{Statistické výsledky parametrů modulace hlasu (vibrata)}

Tab. A7 Hladiny statistické významnosti analýzy rozptylu se čtyřmi faktory (4-way ANOVA) žánr, vokál, výška a SPL.

\begin{tabular}{|c|l|r|r|r|r|}
\hline Modulace & Parametr & \multicolumn{1}{l|}{ Žánr } & \multicolumn{1}{l|}{ Vokál } & \multicolumn{1}{l|}{ Výška } & \multicolumn{1}{l|}{ SPL } \\
\hline \multirow{3}{*}{ Výšková } & Frekvence modulace (Hz) & $\mathbf{3 . 2 9 E}-16$ & 0.1385 & $5.91 \mathrm{E}-06$ & 0.0179 \\
\cline { 2 - 6 } & Rozsah modulace (ST) & $\mathbf{1 . 0 7 E - 2 1 0}$ & 0.7726 & $\mathbf{1 . 0 2 E - 2 8}$ & $\mathbf{3 . 2 1 E - 1 1}$ \\
\cline { 2 - 6 } & Periodická nepravidelnost (\%) & $\mathbf{5 . 7 4 E - 2 8}$ & 0.6094 & 0.1241 & 0.7369 \\
\cline { 2 - 6 } & Rozsahová nepravidelnost (\%) & $5.23 \mathrm{E}-09$ & 0.2854 & 0.0299 & 0.2944 \\
\hline Intenzitní & Frekvence modulace (Hz) & 0.1587 & 0.0806 & $8.33 \mathrm{E}-04$ & 0.808 \\
\cline { 2 - 6 } & Rozsah modulace (ST) & $\mathbf{4 . 4 4 E - 1 6}$ & $2.05 \mathrm{E}-06$ & $\mathbf{1 . 8 2 E}-15$ & 0.0085 \\
\cline { 2 - 6 } & Periodická nepravidelnost (\%) & 0.2108 & 0.8795 & 0.7252 & 0.0073 \\
\cline { 2 - 6 } & Rozsahová nepravidelnost (\%) & 0.3522 & 0.7529 & 0.007 & 0.5852 \\
\hline
\end{tabular}




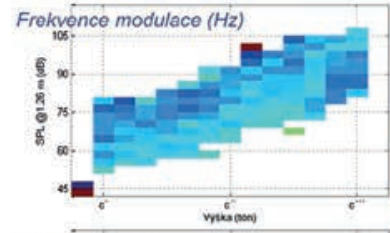

Rozsah modulace (pültón)

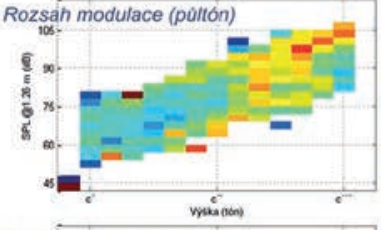

Nepravidelnost periody (\%)

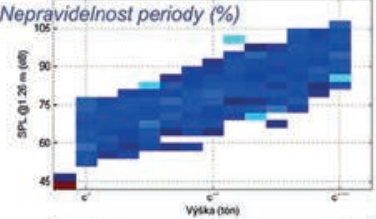

Nepravidelnost rozsahu (\%)

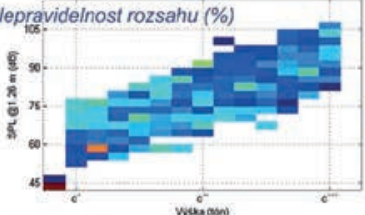

Frekvence modulace (Hz)

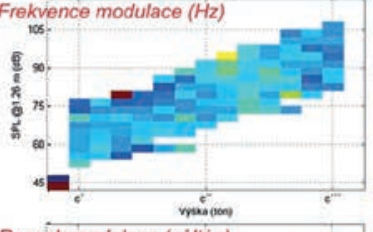

Rozsă modulace (pưltón)

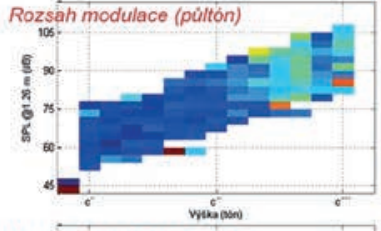

Nepravidelnost periody (\%)

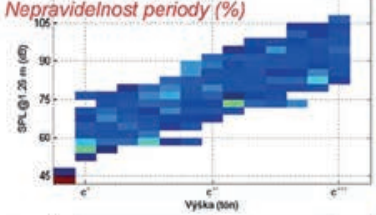

Nepravidelnost rozsahu (\%)

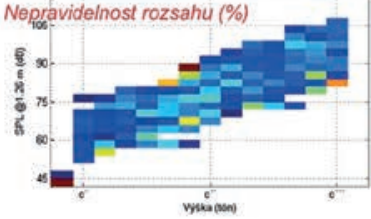

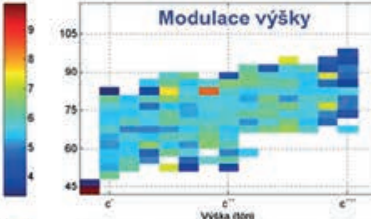
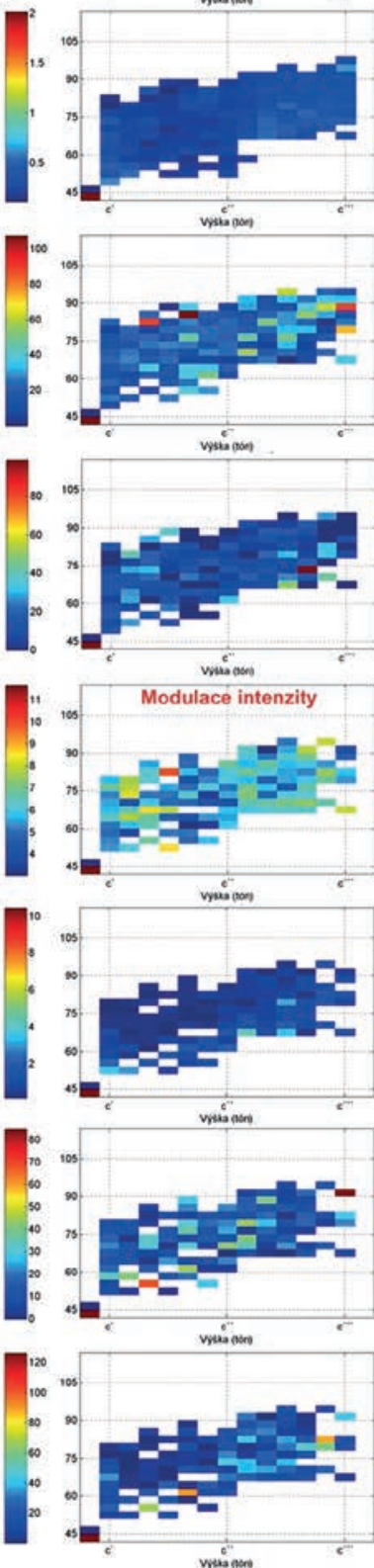
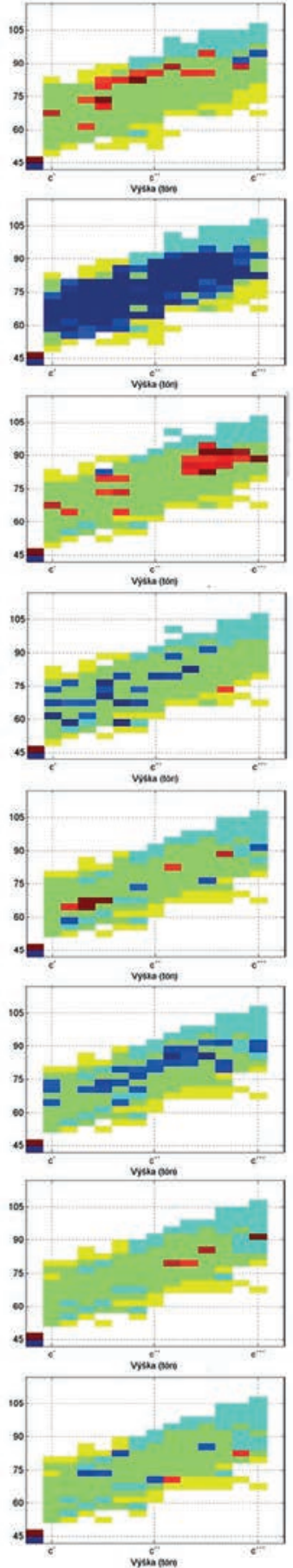

Obr. A2 Rozložení parametrů vibrata v hlasovém poli a jejich porovnání mezi klasickými a popovými zpěvačkami. 


\section{Výsledky elektroglotografického signálu}

Tab. A8 Hladiny statistické významnosti analýzy rozptylu parametru kontaktní koeficient (CQ) se čtyřmi faktory žánr, vokál, výška a SPL a porovnání CQ pro jednotlivé dynamiky s dvěma faktory žánr a výška.

\begin{tabular}{|c|c|c|c|c|}
\hline Par & Žánr & Vokál & Výška & SPL \\
\hline tCQw & 5.37E-15 & 0.0024 & 1.10E-10 & 4.57E-07 \\
\hline$A-f f$ & $1.22 E-08$ & $A$ & 0.2614 & $f f$ \\
\hline I-ff & 0.0085 & $I$ & 0.3292 & $f f$ \\
\hline$U-f f$ & 0.0536 & $U$ & 0.9061 & ff \\
\hline
\end{tabular}

$C Q:$
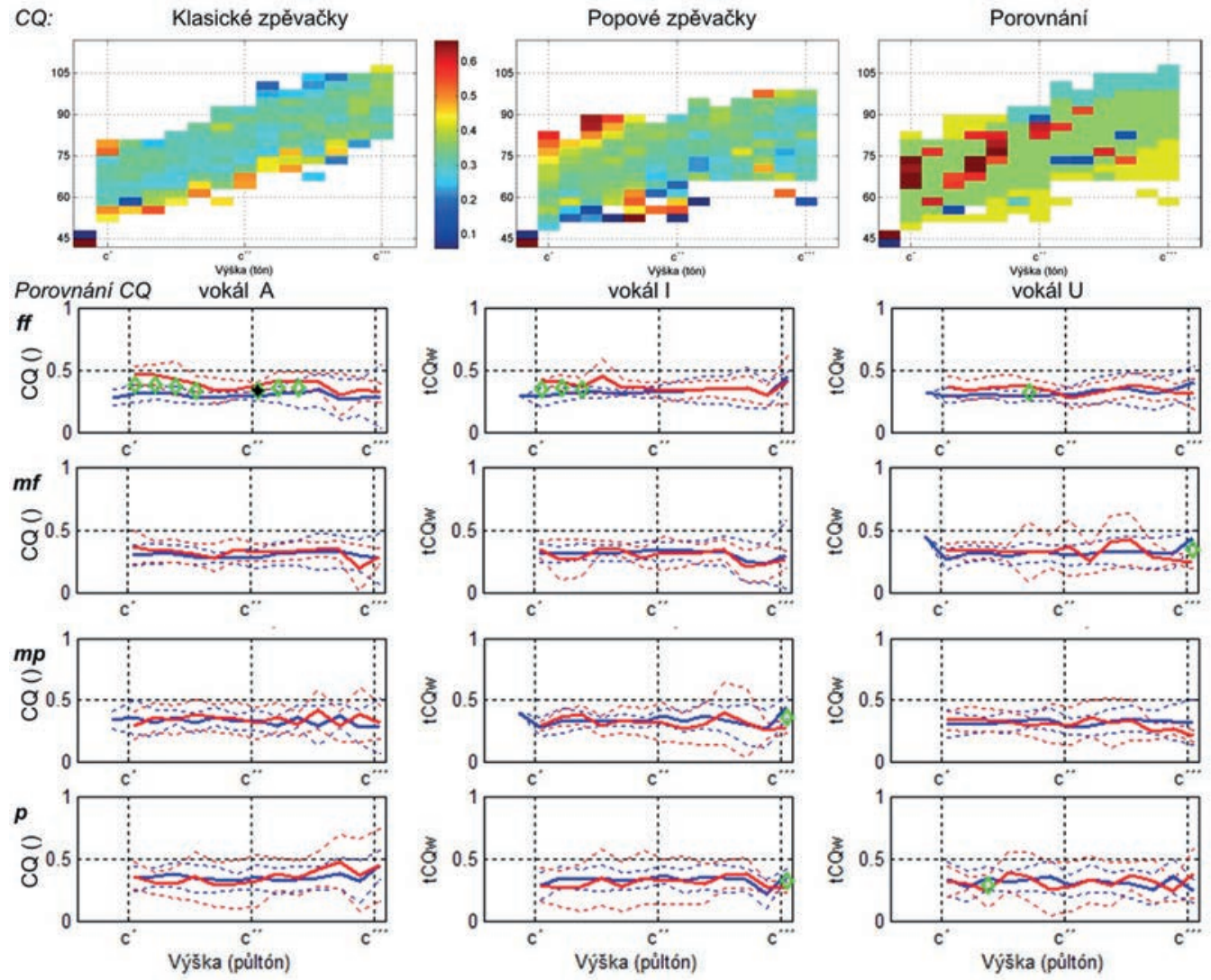

Obr. A3 Porovnání rozložení kontaktního koeficientu (CQ) v měřené oblasti hlasového pole (horní část) a porovnání průměrných hodnot mezi klasickými a popovými zpěvačkami pro jednotlivé dynamiky. 


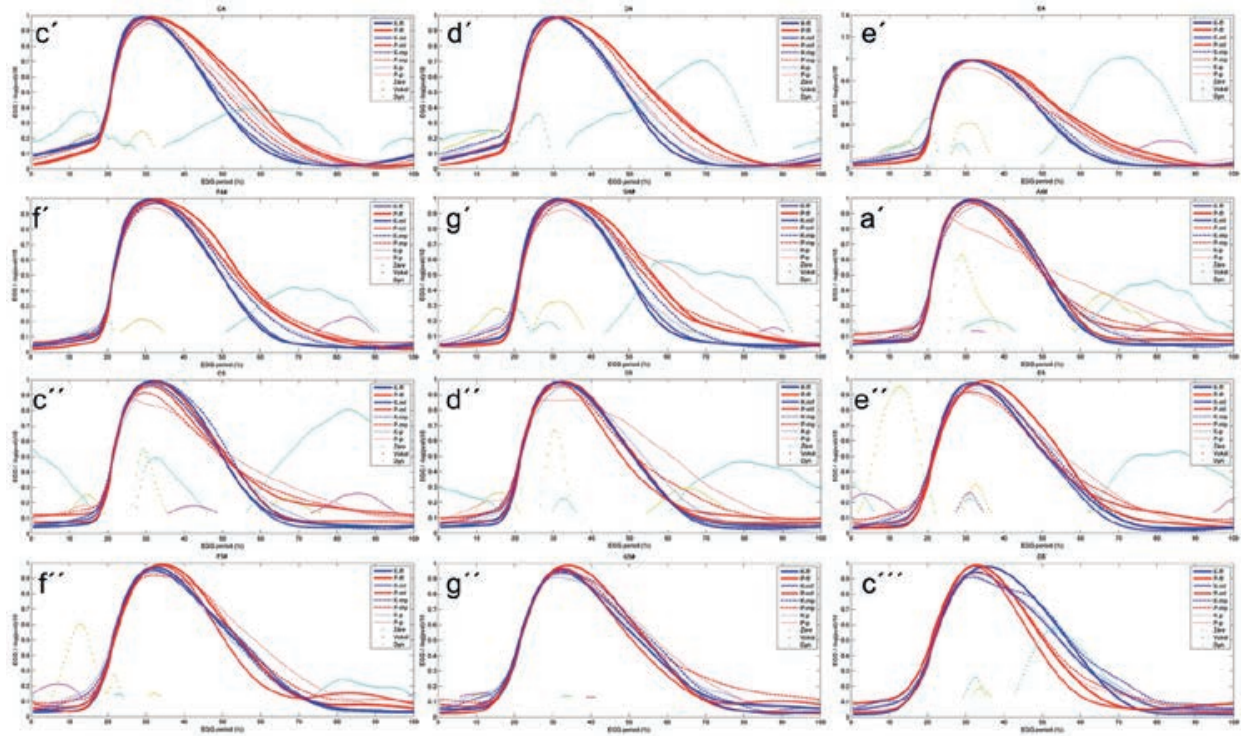

Obr. A4 Porovnání průměrných normalizovaných pulsů EGG (jeden cyklus) pro klasické (modrá) a popové (červená) zpěvačky a čtyři dynamiky (ff - tlustá plná čára, mf - tlustá čárkovaná, mp - tenká čárkovaná čára, $p$ - velmi tenká tečkovaná čára). Tečkovaně jsou znázorněny statistické hladiny významnosti [-log(pval)/10] efektu žánru (tyrkysová), vokálu (fialová) a dynamiky (žlutá).

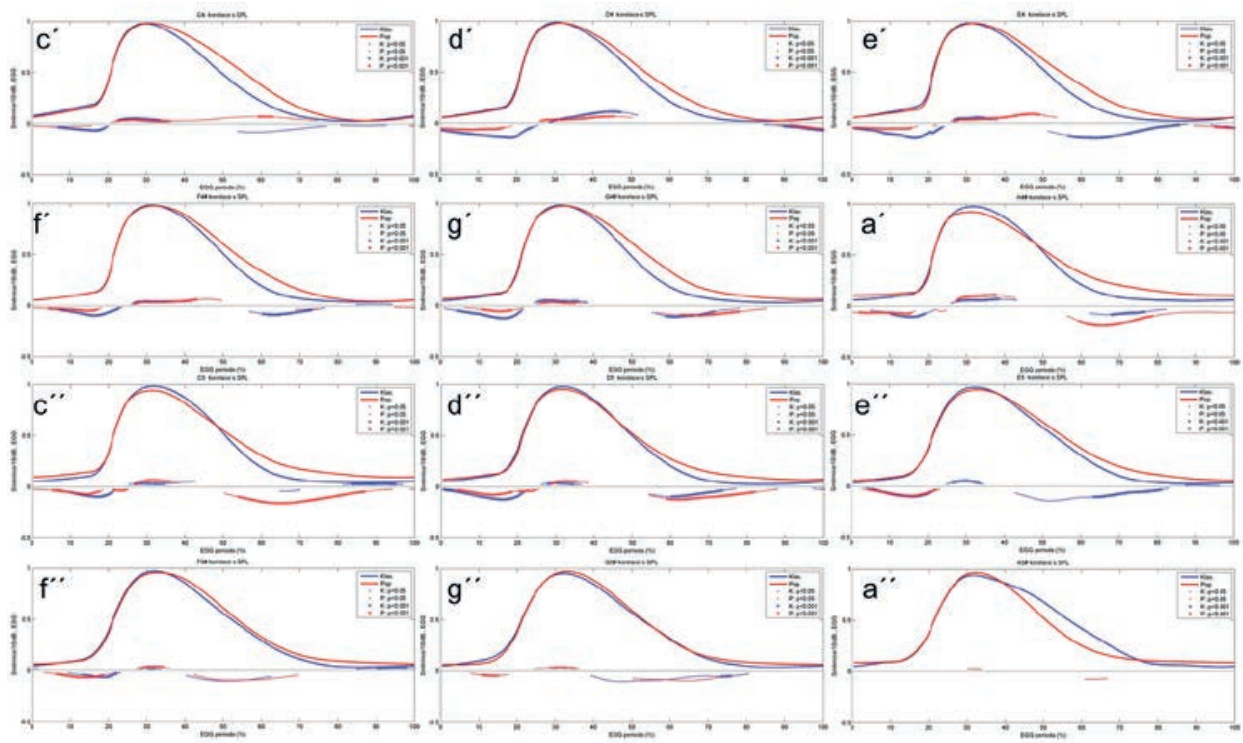

Obr. A5 Průměrné normalizované pulsy klasických a popových zpěvaček a směrnice lineárního trendu s nárůstem SPL. 
Výsledky akustické parametrizace

Tab. A9 Hladiny statistické významnosti 4-cestní analýzy rozptylu akustických parametrů

\begin{tabular}{|c|c|c|c|c|}
\hline Parametr & Žánru & Vokál & Výška & SPL \\
\hline dHa1Ha2 & $2,04 \mathrm{E}-16$ & 0 & 3,57E-161 & $4,75 \mathrm{E}-19$ \\
\hline L(H1) & 6,55E-39 & 0 & $6,19 \mathrm{E}-145$ & 0 \\
\hline COG(2-5 kHz) & 8,17E-52 & $7,48 E-302$ & $2,36 \mathrm{E}-176$ & $8,48 E-49$ \\
\hline $\operatorname{COG}(0-2.5 \mathrm{kHz})$ & $2,47 E-35$ & 0 & 1,17E-195 & $1,96 E-70$ \\
\hline Rolloff85 & 0 & $2,34 \mathrm{E}-66$ & $5,07 E-96$ & $6,20 E-22$ \\
\hline Brightness 3000 & $1,22 \mathrm{E}-120$ & $9,14 \mathrm{E}-117$ & 8,93E-158 & $4,68 E-53$ \\
\hline Inharmonicity & $5,90 \mathrm{E}-13$ & $9,48 \mathrm{E}-17$ & $4,42 E-13$ & $2,41 E-27$ \\
\hline Centroid & 0 & $4,15 E-183$ & $2,25 \mathrm{E}-106$ & $1,69 E-27$ \\
\hline Skewness & 8,97E-305 & $2,80 \mathrm{E}-81$ & $8,19 \mathrm{E}-148$ & $2,49 E-28$ \\
\hline Entropy & $3,04 \mathrm{E}-05$ & $5,05 E-239$ & 1,57E-116 & $2,28 \mathrm{E}-17$ \\
\hline Fullness & $1,09 E-65$ & 0,066 & $1,55 E-21$ & 0 \\
\hline Activity & $6,60 \mathrm{E}-28$ & $3,32 \mathrm{E}-07$ & $1,04 E-88$ & 0 \\
\hline
\end{tabular}

Rozložení standardních akustických parametrů je uvedeno na Obr. A6.

Z celkového porovnání v grafech v první řadě lze vyčíst, že největší rozdíl hladin prvních dvou harmonických složek akustického spektra je jak u klasických zpěvaček, tak u popových, v nejvyšší části měřeného rozsahu, tudíž kolem c' ' ve všech dynamikách. Zároveň popové zpěvačky vykazují vyšší hodnoty než operní zpěvačky v jednočárkované oktávě při samohláskách /a/, / u/, a to především v $m f$ a nižších dynamikách. Naopak nejvyšší hodnoty rozdílů můžeme sledovat u klasických zpěvaček v jednočárkované oktávě ve forte u vokálu A a v dvoučárkované oktávě u vokálu U, pro vokál I je v zásadě situace opačná než u vokálu U.

Hladina první harmonické složky - L(H1) v akustickém spektru závisí na výšce, SPL a zpívaném vokálu. Porovnáme-li klasické a popové zpěvačky vưči sobě, nalezneme podobný trend - s narůstající výškou se zvyšuje i hladina první harmonické složky. Zejména na vokálu /a/ je vidět, že popové zpěvačky dosahují nižších hodnot než klasické, a to zejména v jednočárkované oktávě.

Spektrální těžiště (centroid) v pásmu 2-5 kHz je závislé na samohláskách a výšce. Statisticky systematický rozdíl mezi skupinami zpěvaček zde není tak markantní, nicméně všude, kde se tento rozdíl vyskytuje, dosahují popové zpěvačky vyšších hodnot než klasické. Výjimku tvoří samohláska /i/, při které ve dvoučárkované oktávě nabývají hodnoty klasických zpěvaček více.

Spektrální centroid pásma prvních dvou formantů v rozsahu 0-2,5 kHz je závislý na samohláskách a výšce. U samohlásek /i/ a /u/ se ukazuje pro obě skupiny zpěvaček trend, při němž zpěvačky dosahují vyšších hodnot se stoupající výškou tónu a k nejvyšším 
hodnotám se dostávají až v druhé polovině dvoučárkované oktávy. Vokál /a/ poněkud vybočuje z řady, nebot̉ zpěvačky z obou skupin nedosahují tak malých hodnot jako u ostatních samohlásek, dokonce popové zpěvačky vykazují hodnoty vy̌ší i v jednočárkované oktávě ve forte. Podíváme-li se na grafy porovnání, největší statisticky systematické rozdíly nalezneme právě v grafu u vokálu $\mathrm{A}$, kde je vidět, že popové zpěvačky mají naměřeny vyšší hodnoty než klasické zpěvačky až do poloviny druhé oktávy.
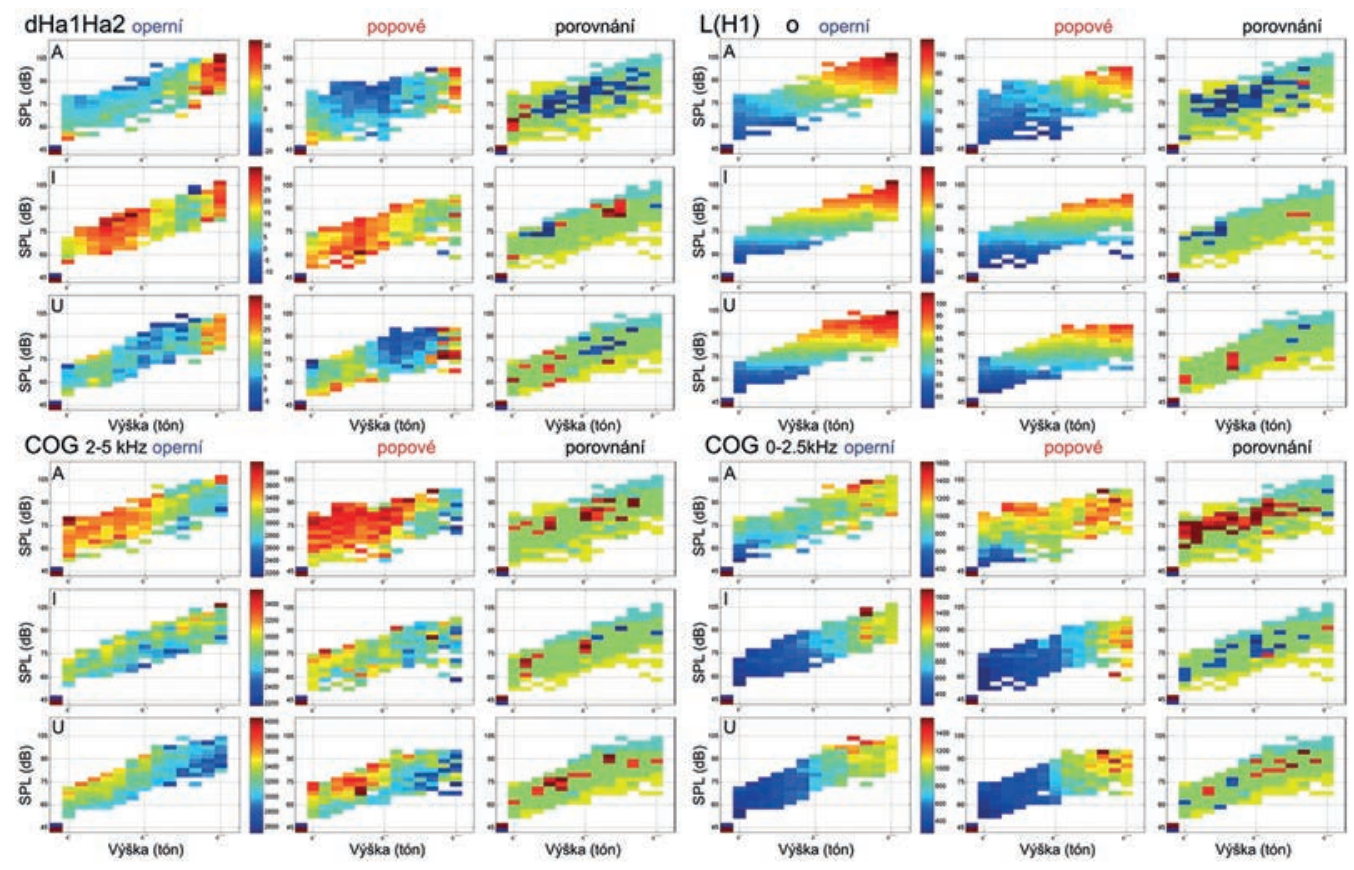

Obr. A6 Rozložení standardních akustických parametrů v hlasovém poli pro jednotlivé vokály a jejich porovnání mezi klasickými a popovými zpěvačkami.

Použité parametry popisují spektrum, většinou z globálního hlediska. Parametr rolloff $85 \%$ určuje frekvenci pod kterou se nachází $85 \%$ energie spektra ${ }^{82} . \mathrm{Z}$ výsledků je patrné, že rolloff (viz Obr. A7 levá horní část) je závislý především na žánru. Zatímco u klasických zpěvaček je $85 \%$ energie spektra v oblasti do $5 \mathrm{kHz}$, u popových zpěvaček je tato hranice posunutá výše a pohybuje se tak mezi $5 \mathrm{kHz}$ a $8 \mathrm{kHz}$. Výjimku u popových zpěvaček tvoři přechod nad c'", kde se rolloff pohybuje výrazně níže.

Parametr brightness $3000 \mathrm{~Hz}$ udává, kolik energie spektra se nachází nad hranicí $3 \mathrm{kHz}^{83}$. Dle našich měření, je tento parametr závislý především na výšce (na frekvenci), ale také na žánru a vokálu. Přechod nad c' 'se projeví poklesem energie nad $3 \mathrm{kHz}$. U popových zpěvaček tento parametr dosahuje obecně vyšších hodnot.

82 LARTILLOT, op. cit., s. 131-132.

83 LARTILLOT, op. cit., s. 133-134. 
Centroid je první statistický centrální moment ${ }^{84}$. Jedná se prakticky o těžiště celého spektra. Centroid u klasických zpěvaček dosahuje maximálně frekvence $3 \mathrm{kHz}$ a v průběhu dvou zkoumaných oktáv se frekvenčně mění minimálně. U popových zpěvaček se mění mnohem výrazněji a obecně se také nachází na vyšších frekvencích. Opět se projeví pokles parametru v oblasti nad c'”.

Entropie rovněž popisuje spektrum ze statistického hlediska. Pokud je ve spektru nějaká složka či oblast prominentní, entropie dosahuje nízkých hodnot. Pokud ve spektru taková složka či oblast chybí a zbytek spektra si je víceméně rovnocenný, entropie roste ${ }^{85} . \mathrm{Z}$ výsledků je patrné, že významné složky se $\mathrm{v}$ případě popových zpěvaček objevujî po přechodu nad c'".
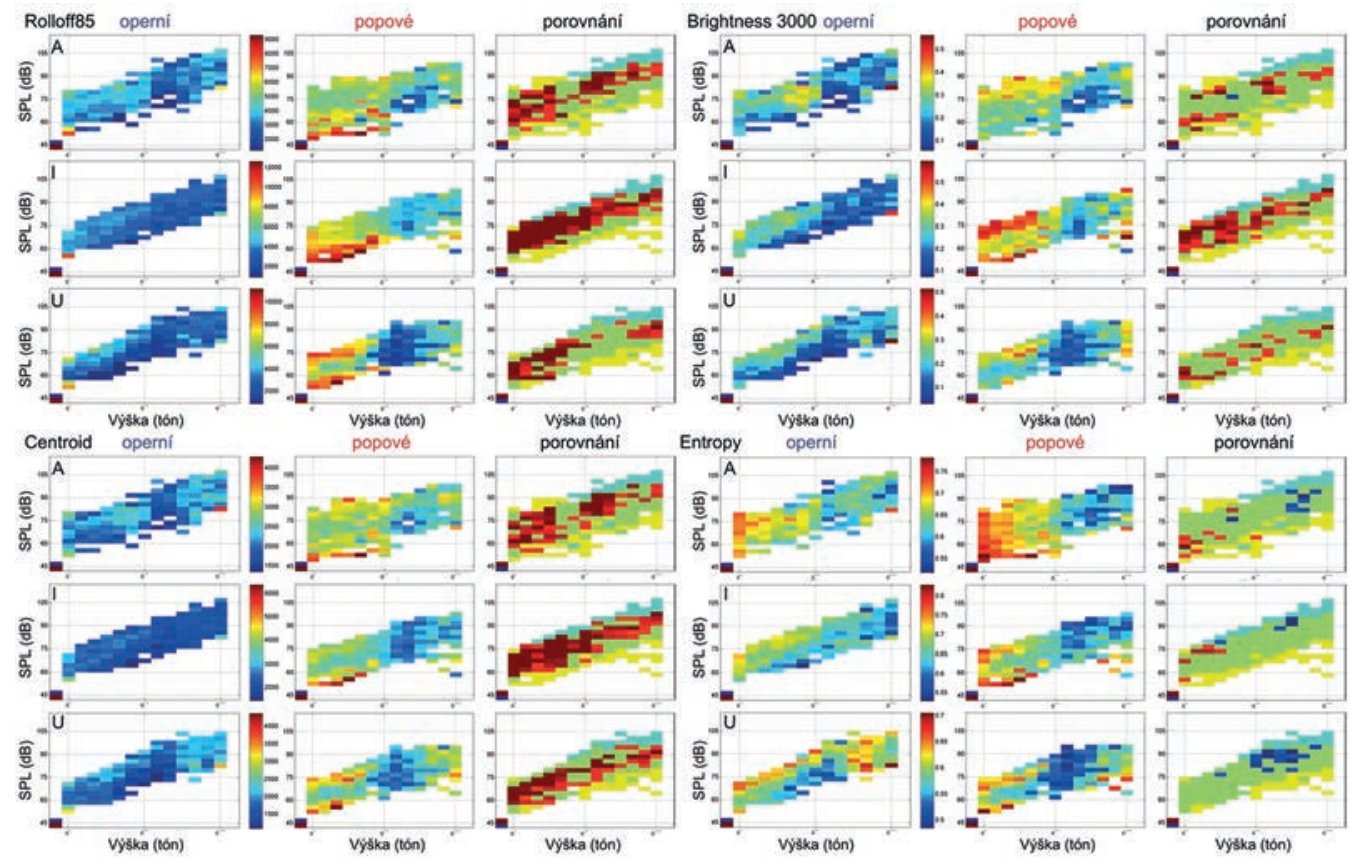

Obr. A7 Rozložení akustických parametrů (Rolloff85, Brightness 3000, Centroid a Entropy) v hlasovém poli pro jednotlivé vokály a jejich porovnání mezi klasickými a popovými zpěvačkami.

Další parametry jsou uvedeny na Obr. A8.

V př́ípadě parametru skewness se jedná o třetí statistický centrální moment, někdy označovaný jako šikmost spektra ${ }^{86}$. U zkoumaných spekter dosahuje vždy kladných hod-

84 LERCH, op. cit., s. 37, 45.

85 LARTILLOT O., op. cit., 2017. MIRtoolbox 1.7 User's Manual. Online, s. 190-191.

86 LERCH A., op. cit., 2012. An Introduction to Audio Content Analysis: Application in Signal Processing and Music Informatics. IEEE Press, s. 38. 
not. Spektra jsou tedy vždy protažena od těžiště směrem doprava a obsahují v tomto směru hodnoty vyšší, než je střední hodnota daného spektra. Čím vy̌šsí hodnoty parametr dosahuje, tím více je spektrum protažené. Ze získaných výsledků je patrné, že šikmost je odlišena především žánrem. Spektra klasických zpěvaček jsou protažena vpravo více než spektra zpěvaček popových. Na velikost pravé strany spektra evidentně působí oblast 3.-5. formantu, které svojí energií výrazněji zešikmí spektrum k vy̌̌ším složkám (doprava). U popových zpěvaček je tento jev jasně vidět po překročení c' '. U klasických zpěvaček nastává dříve - na nejvy̌šších tónech první oktávy.

Parametr inhramonicity vyjadřuje množství vyšších frekvenčních složek nespadajících do harmonické řady ${ }^{87}$. Z výsledků lze vyčíst, že nejvyšších hodnot dosahuje parametr u klasických zpěvaček ve spodní části první oktávy př̌i vyšší hladině SPL. U popových zpěvaček dosahuje parametr nejvyšších hodnot při nízkých hodnotách SPL.

Parametr fullness a activity definovali V. Alluri a P. Toiviainen jako fluktuace výkonové spektrální hustoty v pásmu $50 \mathrm{~Hz}$ až $200 \mathrm{~Hz}$, resp. activity v pásmu $1600 \mathrm{~Hz}-6400 \mathrm{~Hz}^{88}$.
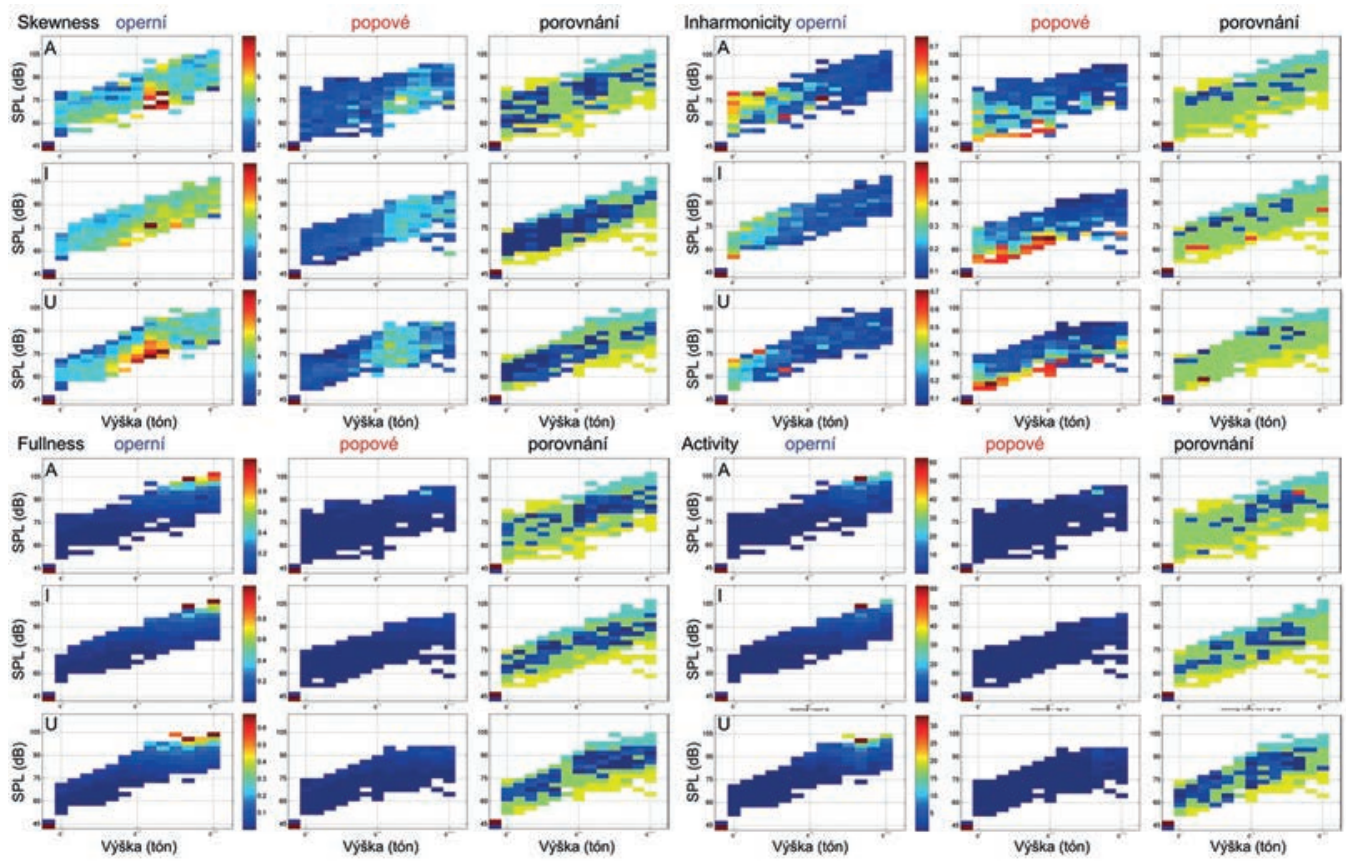

Obr. A8 Rozložení akustických parametrů (Skewness, Inharmonicity, Fullness a Activity) v hlasovém poli pro jednotlivé vokály a jejich porovnání mezi klasickými

$$
\text { a popovými zpěvačkami. }
$$

87 LARTILLOT, op. cit., s. 149-150.

88 ALLURI, 2012 et al., op. cit., s. 3677-3689. 
Zatímco v př́ípadě popových zpěvaček jsou oba parametry prakticky stabilní, u klasických zpěvaček v nejvyšších polohách hodnoty parametru strmě rostou. 
